\title{
APRENDIZAGEM INFORMAL COMO FACILITADORA DA ATUAÇÃO PROFISSIONAL: estudo de caso no Ministério das Relações Exteriores
}

Aline de Aguiar Belsito dos Santos 
TRABALHO DE CONCLUSÃO DE CURSO

\title{
APRENDIZAGEM INFORMAL COMO FACILITADORA DA ATUAÇÃO PROFISSIONAL: estudo de caso no Ministério das Relações Exteriores
}

\author{
Aline de Aguiar Belsito dos Santos \\ Professora Orientadora: \\ Dra. Catarina Cecília Odelius
}

"Trabalho apresentado em cumprimento às exigências acadêmicas parciais da disciplina Estágio Supervisionado em administração para a obtenção do grau de Administradora" 
Santos, Aline de Aguiar Belsito.

Aprendizagem Informal como facilitadora da atuação profissional: estudo de caso no Ministério das Relações Exteriores / Aline de Aguiar Belsito dos Santos. - Brasília, 2009.

$64 \mathrm{f}$ : : il.

Monografia - Universidade de Brasília, Departamento de Administração, 2009.

Orientador: Catarina Cecília Odelius, Drª .

1. Aprendizagem organizacional. 2. Aprendizagem Informal. 
Universidade de Brasília

Faculdade de Economia, Administração, Contabilidade e Ciências da Informação e Documentação

DEPARTAMENTO DE ADMINISTRAÇÃO

\section{APRENDIZAGEM INFORMAL COMO FACILITADORA DA ATUAÇÃO PROFISSIONAL: estudo de caso no Ministério das Relações Exteriores}

A Comissão Examinadora, abaixo identificada, aprova o Trabalho de Conclusão do Curso de Administração da Universidade de Brasília da aluna

\section{Aline de Aguiar Belsito dos Santos}

Catarina Cecília Odelius, Doutora

Professora-Orientadora

Pedro Meneses, Doutor

Professor-Examinador

Brasília, 17 de julho de 2009 
Aos meus pais, irmão, familiares, namorado e amigos, que me motivaram e me auxiliaram incondicionalmente durante a realização deste trabalho.

Esta conquista é nossa. 
Ao final desta jornada, gostaria de agradecer às pessoas que, de certa forma, me conduziram até aqui.

Aos meus pais, pela confiança inabalável e pelos estímulos constantes.

Aos meus avós e padrinhos, que mesmo distantes se fazem presentes por meio de delicadas demonstrações de amor.

Ao meu namorado, por acreditar nos meus sonhos e por ajudar-me a torná-los realidade.

À minha orientadora, Prof. a Catarina, por guiar esta pesquisa com paciência e dedicação.

Às minhas queridas amigas, pela sinceridade, pela companhia e por todos os momentos de intensa alegria que me foram proporcionados.

Aos amigos do M.R.E., pelo amparo, pela força e pelo carinho inteiramente gratuito.

Muito obrigada! 
Aprender é a única coisa de que a mente nunca se cansa, nunca tem medo e nunca se arrepende. (Leonardo da Vinci) 


\section{RESUMO}

O ser humano possui a capacidade de aprender constantemente, seja por novas experiências, pela simples observação ou por meio de conversas e trocas de informações. No ambiente de trabalho, o conhecimento e a aprendizagem têm recebido crescente ênfase devido à idéia de que funcionários bem capacitados e bem preparados são, atualmente, o principal caminho para a obtenção de vantagens competitivas. $O$ presente trabalho teve por objetivo identificar e descrever de que modo acontece a aprendizagem informal de competências necessárias à execução das atribuições exigidas dos profissionais ocupantes do cargo de Assistente de Chancelaria do Ministério das Relações Exteriores, caracterizando-se, dessa maneira, como um estudo de caso único. Esta é uma das carreiras integrantes do Serviço Exterior Brasileiro e sua classe é formada por servidores aprovados em concurso de nível médio. Para realizar esta análise, o estudo propõe a identificação dos processos que possibilitam a ocorrência da aprendizagem informal, a descrição das competências desenvolvidas, a definição da importância das redes sociais para a transferência de informações e conhecimentos, bem como a realização de uma análise comparativa entre servidores empossados em períodos distintos. Visando ao alcance desses objetivos, a pesquisa inicialmente fundamentou-se na revisão da literatura existente, abrangendo os principais conceitos a respeito dos temas abordados por esta pesquisa. A coleta de dados foi realizada por meio do exame de entrevistas semi-estruturadas efetuadas com dois grupos de servidores, empossados em períodos distintos. As informações obtidas foram analisadas e organizadas por grupo, facilitando, dessa maneira, a posterior comparação. A última parte deste trabalho visa à exposição das considerações finais e das principais conclusões obtidas por intermédio da realização da pesquisa, com base em uma análise crítica dos resultados encontrados através das entrevistas realizadas com os dois grupos de servidores, com ênfase nos critérios: desenvolvimento de competências, processos de aprendizagem e redes sociais. Esse capítulo tratará, ainda, da limitações desta pesquisa, principalmente no que diz respeito à análise das redes sociais existentes no Ministério das Relações Exteriores e trará, por fim, sugestões de novas pesquisas que tratem das mesmas temáticas abordadas neste trabalho.

1. Aprendizagem organizacional
2. Aprendizagem

informal 


\section{SUMÁRIO}

1. INTRODUÇÃO

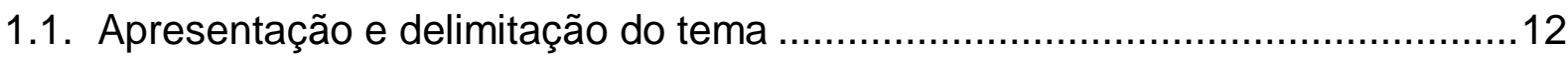

1.2. Descrição da situação problemática.........................................................12

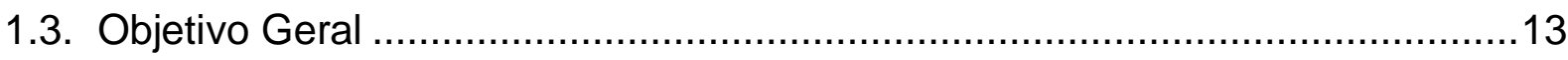

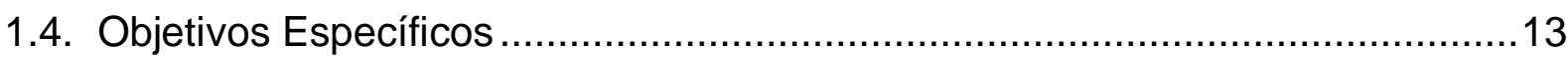

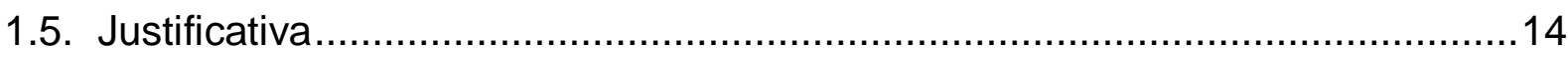

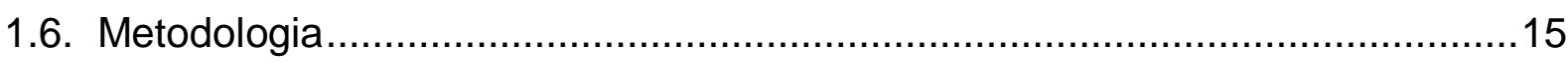

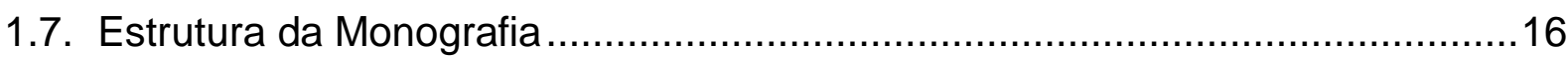

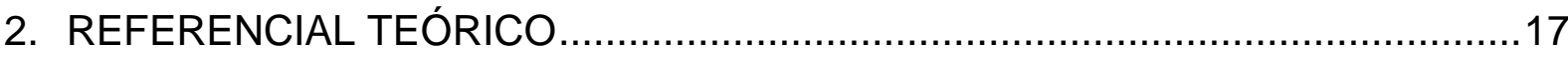

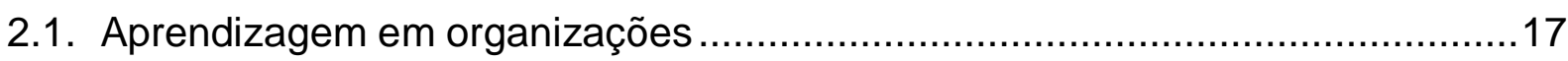

2.2. Vertentes de estudo da aprendizagem em organizações ..............................18

2.2.1. Organizações que aprendem ..........................................................19

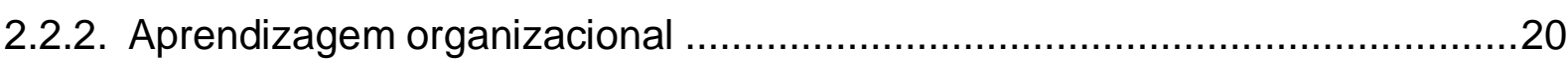

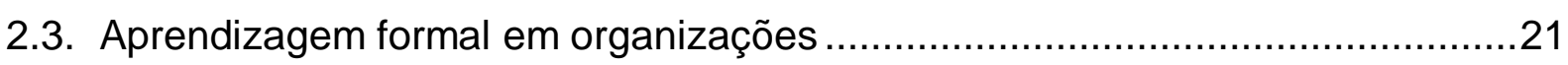

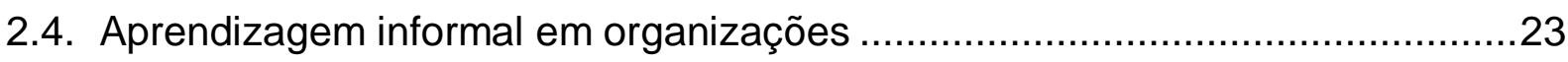

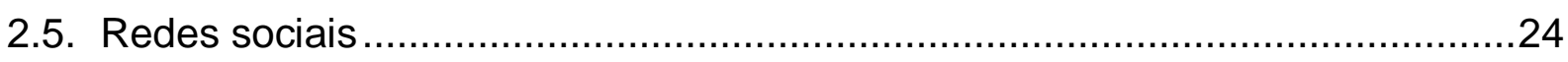

2.5.1. Aprendizagem organizacional em redes sociais .........................................26

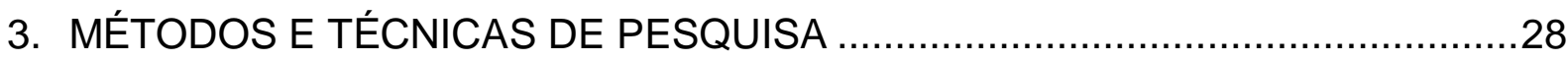

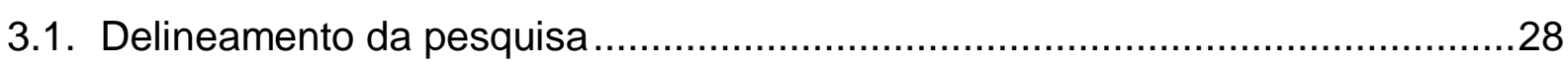

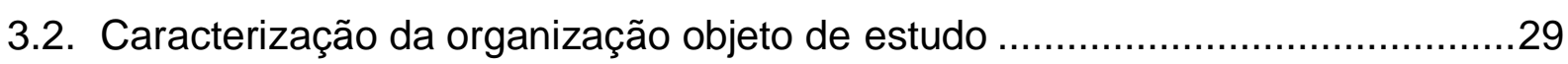

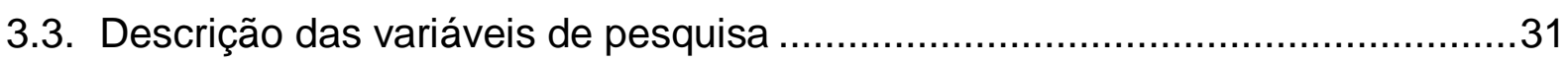

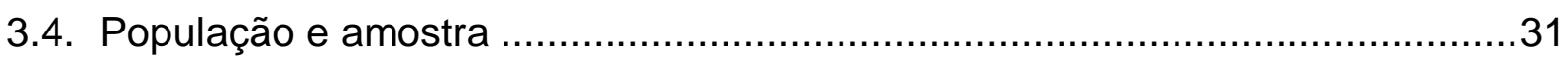

3.5. Procedimentos e instrumentos utilizados na coleta e análise dos dados ..........35

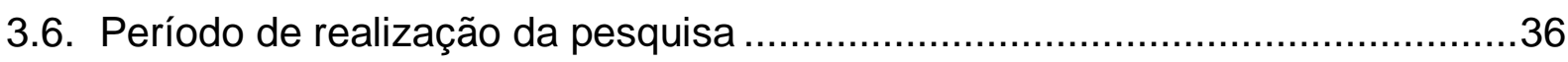

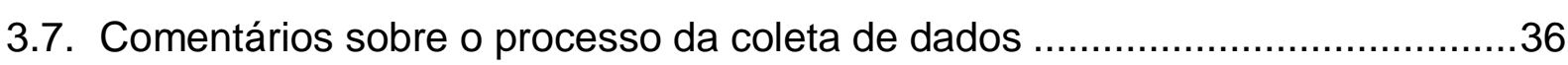

4. APRESENTAÇÃO E ANÁLISE DOS RESULTADOS DA PESQUISA ..................37

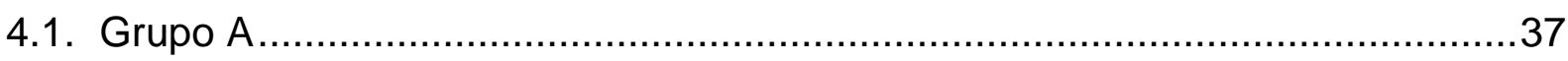

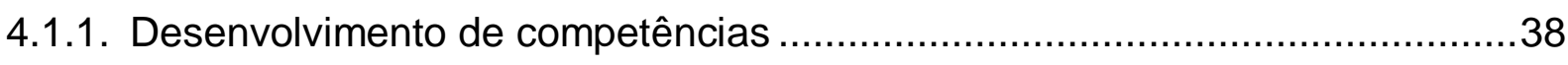

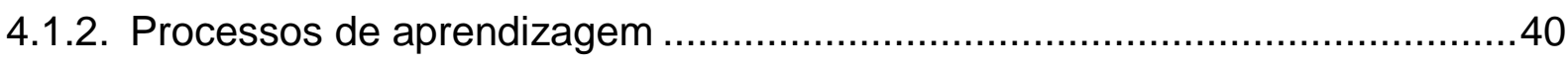

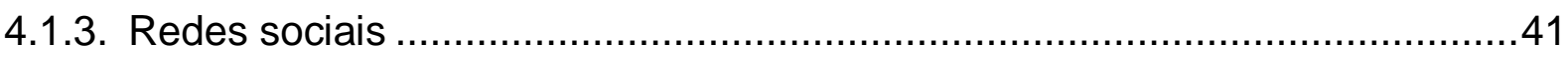

4.1.4. Desenvolvimento de competências por meio de experiência de trabalho no

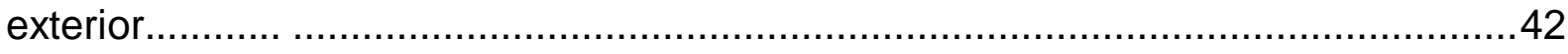

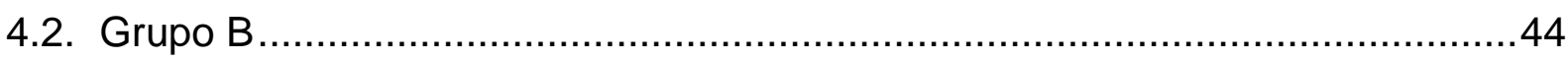


4.2.1. Desenvolvimento de competências ........................................................... 44

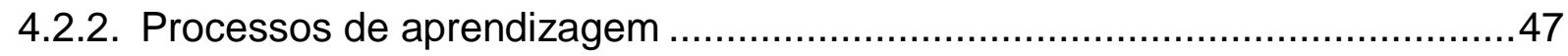

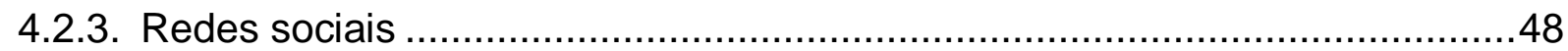

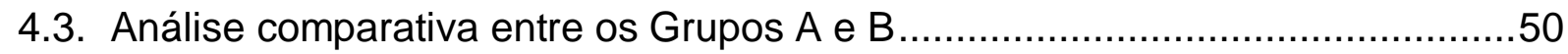

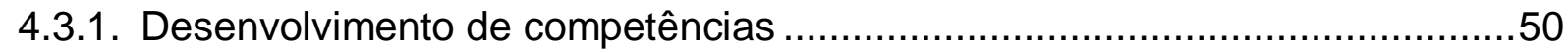

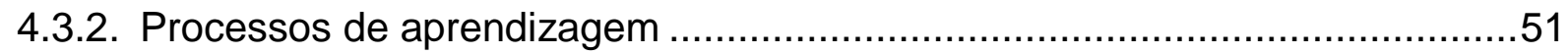

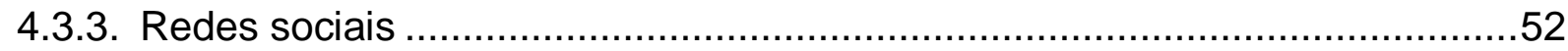

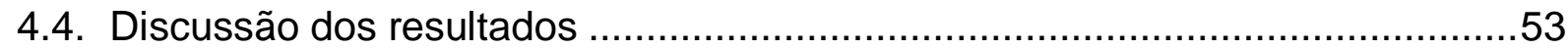

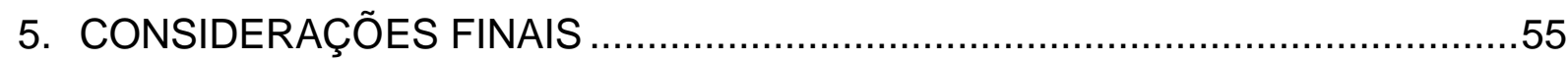

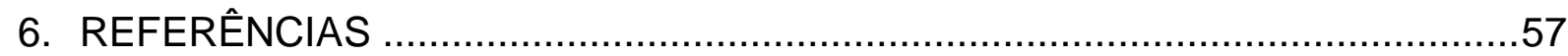

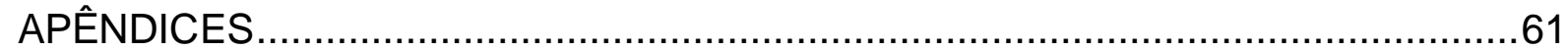

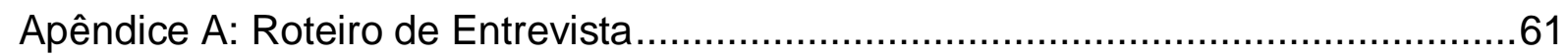

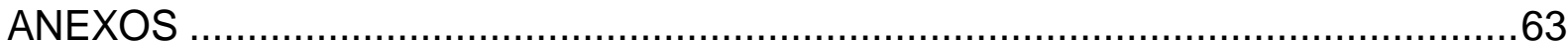

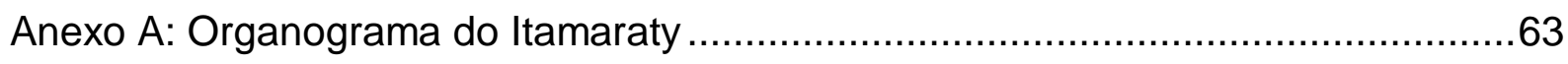




\section{LISTA DE TABELAS E QUADROS}

Tabela 1 - Número total de servidores ativos no Brasil e no Exterior: .......................30

Tabela 2 - Comparativo dos Assistentes de Chancelaria: ......................................32

Tabela 3 - Dados sócio-demográficos do Grupo A:.............................................33

Tabela 4 - Dados sócio-demográficos do Grupo B:.............................................33

Tabela 5 - Servidores do Grupo A que trabalharam no exterior: .............................35

Quadro 1 - Desenvolvimento de competências, de acordo com respondentes do

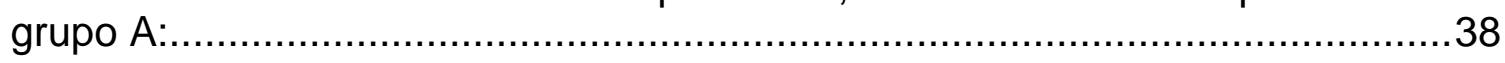

Quadro 2 - Processos de aprendizagem, de acordo com respondentes do grupo A:

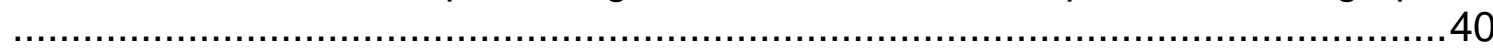

Quadro 3 - Redes sociais, de acordo com respondentes do grupo A::

Quadro 4 - Experiências de trabalho no exterior, de acordo com respondentes do

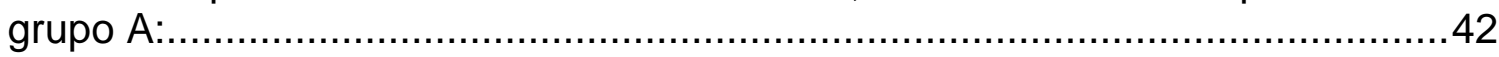

Quadro 5 - Desenvolvimento de competências, de acordo com respondentes do grupo B:

Quadro 6 - Processos de aprendizagem, de acordo com respondentes do grupo B: .

Quadro 7 - Redes sociais, de acordo com respondentes do grupo B: 48

Quadro 8 - Competências citadas pelos entrevistados: 52 


\section{LISTA DE ABREVIATURAS E SIGLAS}

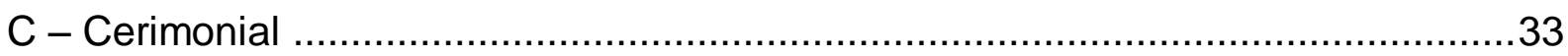

DACC - Divisão da América Central e Caribe ……………...................................33

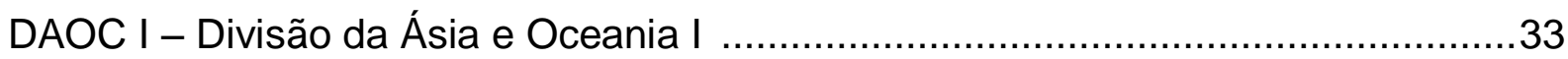

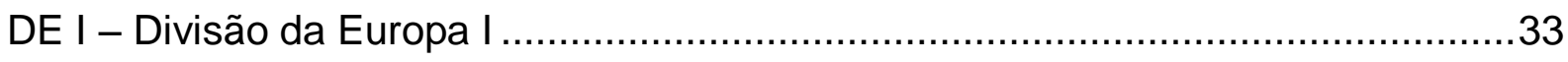

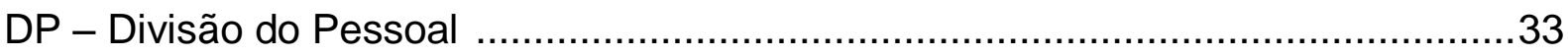

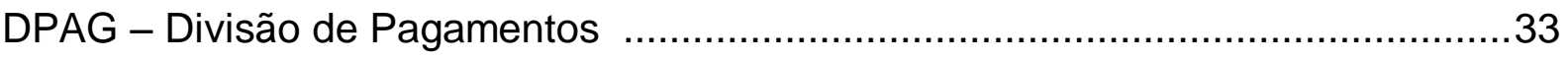

DPB - Divisão de Agricultura e Produtos de Base ..................................................33

DSE - Departamento do Serviço Exterior ..........................................................33

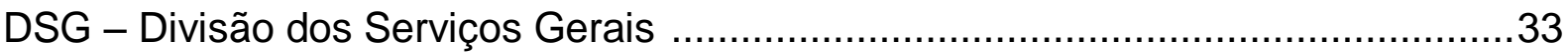

G - Gabinete do Ministro de Estado ...............................................................33

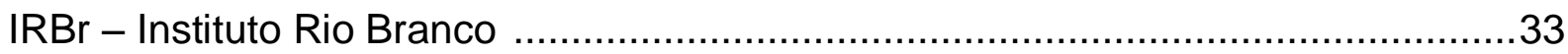

MRE - Ministério das Relações Exteriores. .......................................................29

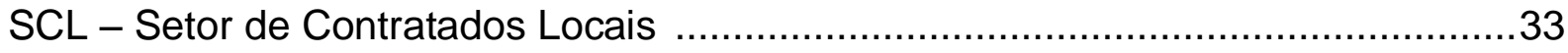




\section{INTRODUÇÃO}

No âmbito organizacional, as competências dos funcionários podem significar uma enorme vantagem competitiva em um mercado impelido por constantes mudanças. A aquisição e o desenvolvimento destas competências ocorrem por meio de processos de aprendizagem que podem ser naturais ou induzidos.

Mesmo em órgãos públicos, que não são impulsionados pela competitividade de mercado, a aprendizagem apresenta um papel de fundamental importância para o desenvolvimento de competências. Abbad e Borges-Andrade (2004) conceituam competência como a capacidade individual de produzir resultados que têm por objetivo atingir as metas e objetivos organizacionais.

O desenvolvimento destas novas competências geralmente é propiciado pela organização por meio de treinamentos, seminários, oficinas e grupos de trabalho. Ocorrem, portanto, em ambientes formais de ensino, onde os indivíduos aprenderão a nova forma de trabalho. Da mesma maneira, existem ambientes de aprendizagem não sistematizados, chamados de sistemas de aprendizagem informal ou natural. Ambos os sistemas oferecem aos indivíduos conhecimentos, habilidades e atitudes que poderão ser aplicadas no contexto do trabalho (BEVILÁQUA-CHAVES, 2007).

Além da inegável importância para a aquisição de conhecimentos, habilidades e atitudes, a aprendizagem organizacional também é vista como um diferencial que influencia diretamente na capacidade de sucesso da instituição. Esses são alguns dos motivos que têm posto em voga a temática da aprendizagem organizacional. Apesar do número crescente de trabalhos realizados, ainda há pouca uniformidade de opiniões a respeito da conceituação e natureza da aprendizagem organizacional. No entanto, os estudos na área de aprendizagem informal em organizações são escassos.

A aprendizagem informal é o tipo de aprendizagem que não é patrocinado pela organização. É composta pelas informações e conhecimentos adquiridos mediante as conversas com os colegas, reuniões, observação, tentativa e erro e até mesmo fora do ambiente de trabalho. 
Neste contexto, esta pesquisa visa explorar o tema da aprendizagem organizacional, com ênfase nos processos informais de aprendizagem e seu poder de desenvolver competências necessárias à execução das atividades diárias. Para isso, efetuará a comparação entre dois grupos distintos de Assistentes de Chancelaria do Ministério das Relações Exteriores, separados com base em seus anos de admissão no órgão.

Desse modo, o estudo em questão pretende investigar as potenciais diferenças existentes nos processos de aprendizagem informal e quais são esses processos, além de identificar as competências desenvolvidas, por meio de entrevistas com servidores selecionados ao acaso pertencentes aos dois agrupamentos escolhidos (empossados em 2005 e empossados em 2008).

\subsection{Apresentação e delimitação do tema}

A pesquisa foi realizada com foco na área de Administração de Recursos Humanos, com ênfase na aprendizagem organizacional informal. Pretendeu-se, com a realização desse estudo de caso, identificar de que maneira ocorre a aprendizagem informal e o desenvolvimento das competências exigidas para o exercício do cargo de Assistente de Chancelaria.

A intenção era identificar quais os principais processos de aprendizagem informal utilizados para a troca de informações, sua importância para o desempenho das funções e desenvolvimento de competências ocasionadas por estes processos. Além disso, o estudo propõe uma análise comparativa entre dois grupos de servidores, empossados em períodos distintos, de modo a identificar possíveis distinções nos processos de aprendizagem.

O Ministério das Relações Exteriores, organização objeto de estudo desta pesquisa, foi escolhido pela conveniência de acesso e de disponibilização dos dados necessários à realização do estudo.

\subsection{Descrição da situação problemática}

Considerando que os indivíduos aprendem a todo o momento, inclusive no ambiente de trabalho, verifica-se que os colaboradores têm, neste espaço, a 
possibilidade de desenvolver conhecimentos, habilidade e atitudes, ou seja, competências específicas, condizentes com as metas organizacionais. Essas competências podem ser desenvolvidas por meio de processos formais e informais de aprendizagem.

Neste sentido, as empresas têm procurado aumentar os investimentos no quadro funcional, baseadas na concepção de que empregados capacitados constituem um diferencial competitivo na medida em que resolvem problemas complexos, assumem riscos e criam soluções (CARVALHO-SILVA, 2008).

Com fulcro nessa idéia, que valoriza o desempenho dos funcionários e o desenvolvimento de competências, esta pesquisa buscou responder à seguinte questão:

Como ocorre a aprendizagem informal de competências necessárias à atuação profissional no exercício do cargo de Assistente de Chancelaria?

\subsection{Objetivo Geral}

Identificar e descrever como ocorre a aprendizagem informal de competências necessárias à atuação profissional no exercício do cargo de Assistente de Chancelaria.

\subsection{Objetivos Específicos}

- Identificar e descrever os principais processos que proporcionam a ocorrência da aprendizagem informal.

- Descrever as competências desenvolvidas por meio do processo de aprendizagem informal.

- Verificar as possíveis diferenças existentes nos processos de aprendizagem informal entre os funcionários empossados em períodos distintos.

- Analisar comparativamente os resultados obtidos com os dois conjuntos de servidores. 


\subsection{Justificativa}

A justificativa, como o próprio nome indica, é o convencimento de que o trabalho de pesquisa deve ser efetivado. Fundamenta-se na apresentação clara e sucinta dos motivos de ordem teórica e/ou prática que justificam a realização do estudo (GIL, 1999).

Ao analisar a importância da aprendizagem em organizações, verifica-se que esta contribui de forma determinante para o processo de aquisição de conhecimentos, habilidades e atitudes. A aprendizagem, nesse contexto, é essencial para o desenvolvimento de competências que permitem ao funcionário a execução dos trabalhos que lhe são requisitados.

Essa pesquisa buscou identificar os principais processos pelos quais ocorre a aprendizagem informal nas organizações e os benefícios que este tipo de aprendizagem traz para o exercício dos afazeres diários dos colaboradores.

A área de estudos sobre aprendizagem organizacional apresenta uma temática de crescente importância na Administração. O interesse pode ser percebido pelo aumento expressivo de trabalhos que abrangem a aprendizagem organizacional. Apesar disso, há pouco consenso na área a respeito dos principais conceitos e definições. Percebe-se, ainda, que pesquisas que focam especificamente nos processos de aprendizagem informal são escassas, surgindo assim a necessidade de abordar esta área tão importante para o desenvolvimento de competências (CARVALHO-SILVA, 2008).

Quanto à contribuição deste trabalho para o Ministério das Relações Exteriores, pode-se afirmar que, com base na identificação dos principais processos de aprendizagem informal e seus conteúdos, o órgão poderá desenvolver uma política de aprendizagem que vise facilitar a transferência de informações e conhecimentos entre funcionários por meio da aprendizagem informal, permitindo, assim, o desenvolvimento e aperfeiçoamento das competências necessárias para o desempenho profissional. 


\subsection{Metodologia}

Segundo Barros e Lehfeld (1986, p.1), a metodologia "examina e avalia as técnicas de pesquisa bem como a geração ou verificação de novos métodos que conduzem à capitação e processamento de informações com vistas à resolução de problemas de investigação". Genericamente, método pode ser compreendido como "o conjunto de processos empregados na investigação e na demonstração da verdade" (CERVO; BERVIAN; SILVA, 2006 p. 27).

O presente estudo caracteriza-se como uma pesquisa qualitativa, uma vez que "faz parte a obtenção de dados descritivos mediante contato direto e interativo do pesquisador com a situação objeto de estudo" (NEVES, 1996, p. 1). Ainda de acordo com este autor, a pesquisa qualitativa "compreende um conjunto de diferentes técnicas interpretativas que visam a descrever e decodificar os componentes de um sistema complexo de significados".

Consiste, ainda, em um estudo de caso que foi realizado no Ministério das Relações Exteriores, exclusivamente com servidores do cargo de Assistente de Chancelaria. Para Yin (2005), o estudo de caso deve ser utilizado quando se almeja lidar com condições contextuais que são altamente pertinentes ao fenômeno estudado.

Quanto aos objetivos, é classificado como um estudo de caso de caráter descritivo. Para Cervo, Bervian e Silva (2006, p. 61), a pesquisa descritiva "procura descobrir, com a maior precisão possível, a freqüência com que um fenômeno ocorre, sua relação e conexão com outros, sua natureza e suas características".

Os dados foram coletados por meio de entrevistas semi-estruturadas, caracterizadas pela busca do entrevistador em "conseguir, por meio da conversação, dados que possam ser utilizados em análise qualitativa, ou seja, os aspectos considerados mais relevantes de um problema de pesquisa" (BARROS; LEHFELD, 1986, p. 110). As entrevistas foram realizadas com duas amostras de servidores retirados de dois grupos distintos: seis funcionários empossados em 2004 e seis funcionários empossados em 2008, visando identificar os principais processos que possibilitaram a aprendizagem por meio de mecanismos informais. As entrevistas foram gravadas e transcritas, para facilitar o processo de análise de dados. 


\subsection{Estrutura da Monografia}

O texto deste trabalho encontra-se organizado em cinco capítulos.

O primeiro capítulo trata da introdução e contextualização do trabalho. Consiste no primeiro contato do leitor com a pesquisa, buscando introduzir e demonstrar seus objetivos gerais e específicos, sua justificativa e sua relevância.

O segundo capítulo aborda os principais conceitos referentes ao tema por meio de uma abrangente revisão da literatura. O objetivo do capítulo II é possibilitar o embasamento teórico deste trabalho, por meio de definições de termos essenciais para o entendimento do estudo, tais como: aprendizagem organizacional, aprendizagem informal e desenvolvimento de competências.

O terceiro capítulo compreende a parte de metodologia utilizada na pesquisa e os instrumentos utilizados para a coleta de dados.

O quarto capítulo apresenta a maneira pela qual os dados necessários foram obtidos, os principais resultados das entrevistas e uma análise comparativa entre os dois grupos objetos de estudo.

Por fim, o quinto capítulo trará as considerações finais desta pesquisa e as principais questões para estudos futuros. 


\section{REFERENCIAL TEÓRICO}

O propósito deste capítulo é agrupar algumas das principais concepções e citações científicas a respeito dos temas abordados por esta pesquisa.

Os conceitos aqui apresentados abrangem inicialmente os aspectos mais gerais da pesquisa, partindo paulatinamente aos pontos específicos deste trabalho.

\subsection{Aprendizagem em organizações}

De acordo com Finger e Brand (2001 apud PERIN et.al, 2006), a crença de que a aprendizagem e a inovação são essenciais para a sobrevivência em ambientes competitivos permitiu que houvesse, nas duas últimas décadas, um crescente interesse pelo processo de aprendizagem no âmbito da organização.

Esta afirmação é validada por Loiola, Néris e Bastos (2006, p.114), que definem a aprendizagem organizacional como:

a capacidade de aprender que permite desenvolver
competências, gerando impactos positivos sobre a
sustentabilidade de condições de competitividade e de
sobrevivência das organizações.

Para Dogston (1993 apud SOUZA, 2004), a aprendizagem organizacional é vista como a busca de manter e desenvolver competitividade, produtividade e inovação em condições tecnológicas e de mercado incertas.

Souza (2004, p.3) afirma ainda que "a preocupação em favorecer aprendizagens emerge em um contexto competitivo no qual inovação em produtos e processos é nuclear à sobrevivência de organizações."

Nestas circunstâncias, torna-se nítido o grande valor que se passou a dar à "aquisição, à manutenção e à transferência do conhecimento como ferramenta estratégica e de sustentabilidade das organizações e como instrumento de empregabilidade para os trabalhadores" (ABBAD; BORGES-ANDRADE, 2004, p. 237). Dessa maneira, a aprendizagem assume, principalmente a partir da década de 1990, a condição de um dos temas mais pesquisados na esfera organizacional.

Vale ressaltar que, no serviço público, apesar de não encontrarmos o nível de competitividade de mercado disposto pelos autores, há, ainda assim, 
valorização da aprendizagem organizacional. Para os servidores públicos, o conhecimento adquirido pode significar a obtenção de funções gratificadas ou Cargos de Direção e Assessoramento Superiores, os chamados DAS, além do status por meio do reconhecimento da qualidade do trabalho exercido, objetivo buscado por funcionários, independente da esfera pública ou privada.

Mais importante ainda, a aprendizagem organizacional no serviço público possibilita, por meio do desenvolvimento de diversas competências, um atendimento efetivo à sociedade e aos cidadãos. Dessa maneira, servidores bem preparados podem significar a prestação de um serviço de excelência, que viria a suprir interesses não apenas de um órgão público específico, mas sim de toda população usuária do serviço.

Atualmente, o ambiente do mercado de trabalho exige aquisição constante de novos conhecimentos e habilidades, ou seja, novas aprendizagens. Dispor de múltiplos saberes tornou-se imprescindível e demanda uma integração e relativização do conhecimento que transcende a simples necessidade de memorizar e reproduzir (POZO, 2002). Portanto, para que os indivíduos possam se inserir no mercado, se faz necessária a busca pela diminuição do gap existente entre o que supõe em termos de CHAs e o que realmente a pessoa apresenta.

\subsection{Vertentes de estudo da aprendizagem em organizações}

A aprendizagem é um assunto que possui atualmente uma posição de destaque. Entretanto, os autores que tratam da aprendizagem no âmbito organizacional não apresentam um consenso em termos de sua definição, operacionalização e metodologia (GAVIN, 1993 apud PERIN, 2006).

De acordo com Argyis e Schön (1974 apud LOIOLA; NÉRIS; BASTOS, 2006), o campo de estudos sobre aprendizagem organizacional possui duas grandes vertentes: a da aprendizagem organizacional, representada, especialmente, pelos pesquisadores acadêmicos; e a vertente das organizações que aprendem, desenvolvida, sobretudo, por consultores e pesquisadores orientados para a transformação organizacional. 
A abordagem da aprendizagem organizacional versa a respeito das dimensões específicas do processo de aprendizagem, enquanto a da organização de aprendizagem refere-se às dimensões ou características da organização como entidade que busca ou é agente desse processo de aprendizagem (EASTERBYSMITH, 1997 apud PERIN, 2006).

Os acadêmicos e pesquisadores normalmente enfatizam a criação de teorias sobre o fenômeno da aprendizagem organizacional, analisando processos e fatores associados, com base em pesquisas empíricas e investigações realizadas de acordo com a metodologia científica. De maneira distinta, consultores e gestores geralmente focam o que as organizações devem fazer para aprender, com base em análises de experiências práticas bem sucedidas e generalizadas a outros contextos (LOIOLA; NÉRIS; BASTOS, 2006).

Com o contato inevitável que existe entre esses dois rumos de análise, a pesquisa acadêmica sofre influência das idéias e modelos gerados no contexto de consultorias e vice-versa, revelando as distinções e fontes de debates entre as duas vertentes (BASTOS; GONDIM; LOIOLA, 2004).

\subsubsection{Organizações que aprendem}

As organizações que aprendem, segundo Garvin (1993 apud BASTOS; GONDIM; LOIOLA, 2004), são instituições capazes de adquirir, criar, produzir novos insights, transferir conhecimentos e alterar o comportamento de seus integrantes.

Senge (1990) afirma que uma organização de aprendizagem possui um ambiente que permite que os indivíduos ampliem sua capacidade de inovar, permitindo a obtenção de novas formas de pensamentos e a conscientização de que a aprendizagem envolve colaboração mútua. Schaw (1994 apud BASTOS; GONDIM; LOIOLA, 2004) defende que organizações que aprendem são capazes de contrair conhecimentos, modificando seu funcionamento a partir do confronto de suas experiências pessoais com as de terceiros.

De acordo com Bastos, Gondim e Loiola (2004), as principais características desta vertente são as seguintes: aprendizagem é considerada uma vantagem competitiva, que permite que a empresa se adapte com maior 
flexibilidade às mudanças, além do caráter prescritivo de seus autores, que atuam como consultores almejando solucionar os problemas das organizações de seus clientes.

\subsubsection{Aprendizagem organizacional}

A perspectiva da aprendizagem organizacional, por sua vez, se depara com o desafio de conceituar este fenômeno. Há enorme variabilidade de conceitos, pois cada autor observa a aprendizagem organizacional por diferentes níveis de análise: individual, grupal ou organizacional. Para Bastos, Gondim e Loiola (2004), um dos grandes obstáculos que os interessados no tema se deparam "é a adequada transposição de conhecimentos produzidos na psicologia individual para o contexto organizacional".

Na opinião de alguns autores, a aprendizagem organizacional não existe e nem pode existir, já que apenas o indivíduo pode aprender. O que existe é a aprendizagem individual em contexto organizacional (SIMON, 1991 apud SANTANA, 2005). Outros acreditam que toda a aprendizagem, mesmo a individual, é um fenômeno de cunho social.

De acordo com Bastos, Gondim e Loiola (2004), os autores que limitam a aprendizagem ao nível individual defendem que o indivíduo age e aprende na organização. Os que enfocam na organização ressaltam o fato de que a aprendizagem organizacional é algo diferente do simples somatório das aprendizagens individuais.

Para Souza (2004), a aprendizagem é ao mesmo tempo um processo individual e coletivo. A autora defende que a aprendizagem individual e a aprendizagem organizacional são processos distintos, sendo que não ocorre aprendizagem organizacional sem a aprendizagem individual. Ainda, afirma que as organizações diferem-se dos indivíduos ao desenvolverem e manterem sistemas de aprendizagem que, além de influenciar seus membros imediatos, são transmitidos para outros por meio de normas organizacionais e histórias.

Simon (1969 apud SOUZA, 2004, p. 7) define a aprendizagem organizacional como "o crescimento de insights e reestruturações bem sucedidas 
de problemas organizacionais por indivíduos que têm impacto nos elementos estruturais e nos resultados da organização."

Abbad e Borges-Andrade (2004) afirmam que a aprendizagem é um processo que se acontece exclusivamente no nível dos indivíduos, sendo que seus efeitos podem se pela organização como um todo. Bastos, Gondim e Loiola (2004, p. 224) ressaltam que a maioria das argumentações considera a idéia de que a aprendizagem passa a ser organizacional "no momento em que, transcendendo a cada individuo em particular, os conhecimentos, as atitudes, as visões e as práticas tornam-se compartilhadas pelo coletivo".

Esse compartilhamento possibilitaria a criação de estruturas ou rotinas que explicitam novas formas de agir na organização. Concluiu-se, dessa forma, que "o eixo central está na criação de processos de comunicação e espaços apropriados, que permitam a troca de experiências, significados, crenças e valores individuais, o que auxiliaria na construção de modelos compartilhados" (BASTOS; GONDIM; LOIOLA, 2004 p.224).

\subsection{Aprendizagem formal em organizações}

Para que os indivíduos possam desenvolver novas competências, as organizações investem em treinamentos, grupos de trabalho, oficinas e seminários. $O$ recebimento destas instruções normalmente ocorre em ambientes formais de ensino, aonde as pessoas aprenderão a nova forma de trabalho (BEVILÁQUACHAVES, 2007). Nesta contextualização, "as organizações passaram a propiciar condições favoráveis à aprendizagem contínua, que incluem processos distintos e complementares": treinamento, desenvolvimento e educação (ABBAD; BORGESANDRADE, 2004, p. 270).

Abbad e Borges-Andrade (2004) definem o processo de Treinamento, Desenvolvimento e Educação como procedimentos organizacionais que utilizam uma tecnologia instrucional ou são deliberadamente arranjados. Essas ações têm por objetivo a aquisição de conhecimentos, habilidades e atitudes (CHAs) que superem deficiências de desempenho no trabalho, prepare funcionários para novas atribuições, adapte mão-de-obra para a introdução de novas tecnologias ou promova o livre crescimento dos integrantes de determinada instituição. 
Os mesmos autores explicam que treinamento visa à otimização do desempenho do funcionário no cargo em que ele ocupa, enquanto a educação faz referencia às oportunidades propiciadas pela instituição para o desenvolvimento do potencial do colaborar, permitindo que este ocupe novos cargos. desenvolvimento, por sua vez, tem relação com as oportunidades proporcionadas pela organização que possibilitem o crescimento pessoal do empregado.

Segundo Abbad, Borges-Ferreira e Nogueira (2006 apud BEVILÁQUACHAVES, 2007), as ações de treinamento e educação corporativa são estratégias de indução da aprendizagem em ambientes organizacionais e de trabalho.

Para Beviláqua-Chaves (2007), a aprendizagem compreende quatro fases relacionadas: aquisição, retenção, generalização e transferência. A aquisição é caracterizada pela identificação do novo material exposto ao aprendiz. A retenção é compreendida como o processo que ocorre na memória de curto prazo, em que há a codificação do material aprendido de acordo com as experiências pessoais. A generalização acontece com a utilização do material armazenado em outros ambientes, distintos do ambiente em que houve a coleta. Após esta fase, o conhecimento é armazenado na memória de longo prazo, podendo ser aplicado em outros contextos. Por fim, na transferência os conhecimentos aprendidos são utilizados em situações parecidas com a em que houve o aprendizado (transferência lateral) ou quando os conhecimentos embasam a emissão de comportamentos superiores aos ensinados (transferência vertical).

São esperados como resultado das ações de Treinamento, Desenvolvimento e Educação, de acordo com Abbad e Borges-Andrade (2004): que os indivíduos fiquem satisfeitos com o processo; que aprendam; e que ocorram transferências de aprendizagem para o trabalho e transferências para o desempenho das equipes e das organizações. Verifica-se, dessa maneira, a relação existente entre as fases do aprendizado e as conseqüências aguardadas dos processos formais de aprendizagem.

De acordo com Abbad, Borges-Ferreira e Nogueira (2006 apud BEVILÁQUA-CHAVES, 2007), "ações de treinamento e educação corporativa são estratégias de indução da aprendizagem em ambientes organizacionais e de trabalho". Afirma-se que esta a aprendizagem é induzida "porque ocorre em situações estruturadas de ensino, onde o objetivo principal e maximizar a eficácia 
dos processos de aquisição, retenção, generalização e transferência de novos conhecimentos".

\subsection{Aprendizagem informal em organizações}

Nas organizações, nem todas as situações que geram aprendizagem são decorrentes de ações formais de treinamento, desenvolvimento e educação. É necessário enfatizar a importância dos processos de aprendizagem naturais ou informais.

Para Abbad e Borges-Andrade (2004, p. 241), a aprendizagem informal caracteriza-se por "mecanismos informais por meio dos quais ocorrem a transmissão de conhecimentos e a disseminação de novas tecnologias de trabalho".

Ainda de acordo com esses autores, "as pessoas podem estar o tempo todo aprendendo." Esta afirmação ratifica o conceito anterior, demonstrando que o processo de aprendizagem não possui necessariamente uma relação de dependência com mecanismos exclusivamente formais.

Para Day (1998 apud BEVILÁQUA-CHAVES, 2007), a aprendizagem informal no trabalho é qualquer aprendizagem que ocorre aonde o processo de aprendizagem não pode ser determinado ou foi desenhado pela organização.

Exemplificando a idéia da aprendizagem informal, Krogh, Ichijo e Nonaka (2001, p. 159 apud TOMAÉL; ALCARÁ; DI CHIARA, 2005, p. 94) declaram que:

As conversas nas organizações de negócios geralmente apresentam dois objetivos básicos: confirmar a existência e conteúdo do conhecimento ou criar novos conhecimentos [...] o intercâmbio de idéias, opiniões e crenças propiciado pelas conversas possibilita o primeiro e mais importante passo para a criação do conhecimento: o compartilhamento do conhecimento tácito dentro da comunidade da rede.

Abbad e Borges-Andrade (2004) declaram, ainda, que no trabalho os indivíduos podem aprender de distintas formas, como, por exemplo, por meio das conseqüências organizacionais resultantes de seus comportamentos, observando as conseqüências dos comportamentos dos integrantes restantes da equipe, ouvindo histórias de seus colegas mais antigos ou recebendo esclarecimentos de seus supervisores ou de outras pessoas definidas pela organização. 
A aprendizagem informal está intimamente ligada às necessidades específicas do trabalho para a resolução de problemas, aquisição de novos conhecimentos ou habilidades práticas e interpessoais, de maneira que os conteúdos aprendidos têm a propensão de serem utilizados de imediato (DAY, 1998 apud CARVALHO- SILVA, 2008).

Abbad e Borges-Andrade (2004, p. 260) ressaltam que esta forma de aprendizagem "ocorre de modo pouco sistemático, e de acordo com as preferências, ritmo e os estilos pessoais."

A importância dos processos de aprendizagem informal no ambiente de trabalho é tamanha que, de acordo com Day (1998 apud CARVALHO-SILVA, 2008), pesquisadores detectaram que $70 \%$ da aprendizagem ocorre de modo informal, por meio de conversas com colegas, reuniões ou mesmo no trato com os clientes. Apesar da relevância inegável dos processos de aprendizagem informal, as organizações ainda têm dificuldade em reconhecê-los (YORKS, 2000 apud CARVALHO-SILVA, 2008) e considerá-los como fundamentais para a execução das atividades e melhoria do desempenho dos funcionários.

Para distinguir as formas de aprendizagem, Day (1998 apud BEVILÁQUACHAVES, 2007) compara os dois tipos de aprendizagem: o formal e o informal. Para a autora, a aprendizagem informal se molda às necessidades do funcionário, sendo por esta razão tão importante para a sua atuação profissional Além disso, a aprendizagem informal aparece espontaneamente e permite um aprendizado diferenciado, realçando o que realmente deve ser aprendido. A aprendizagem formal, por outro lado, tem importância variável porque existe a possibilidade que esta não seja praticável por cada indivíduo. Ademais, é um tipo de aprendizagem programada e direcionada a um conjunto pré-definido pela organização de conhecimentos, habilidades e atitudes.

\subsection{Redes sociais}

Segundo Tomaél, Alcará e Di Chiara (2005), é inerente ao ser humano o agrupamento entre semelhantes a fim de estabelecer relações de interesse, dentre as quais se pode citar as relações de trabalho e as relações de amizade. Estes 
grupos formados por indivíduos que compartilham os mesmos objetivos podem ser chamados de redes sociais.

Para Marteleto (2001, p. 72), as redes sociais representam "um conjunto de participantes autônomos, unindo idéias e recursos em torno de valores e interesses compartilhados."

Tomaél, Alcará e Di Chiara (2005) definem as redes sociais como estruturas não lineares, flexíveis e descentralizadas, auto-organizáveis e sem limites definidos, que se fundamentam em relações horizontais de cooperação.

Confirmando esta idéia, Costa et al. (2003, p. 73 apud TOMAÉL; ALCARÁ; DI CHIARA, 2005, p. 94) afirmam que a rede pode ser definida como "uma forma de organização caracterizada fundamentalmente por sua horizontalidade, isto é, pelo modo de inter-relacionar os elementos sem hierarquia."

A rede atua como um espaço de interação, proporcionando o alcance de informações imprevisíveis e determinadas por um objetivo que naquele momento aciona a rede, contribuindo para a constituição da sociedade e seu direcionamento (TOMAÉL; ALCARÁ; DI CHIARA, 2005).

É importante salientar que as redes presumem sempre aglomerações, são fenômenos coletivos, seu funcionamento depende do relacionamento de grupos, pessoas ou comunidades (TOMAÉL; ALCARÁ; DI CHIARA, 2005). Na prática, cada indivíduo participa de muitos círculos de relacionamento, mas sem identificá-los ou mensurar quantos são. Geralmente as pessoas só enxergam a rede quando necessitam dela (COSTA et al., 2003, p. 69 apud TOMAÉL; ALCARÁ; DI CHIARA, 2005, p. 94).

Verifica-se, atualmente, mudanças na configuração das redes sociais. Com o advento do desenvolvimento dos meios de comunicação, com ênfase na revolução proporcionada pela Internet, os grupos gozam de inteira autonomia com relação ao tempo e/ou do espaço (TOMAÉL; ALCARÁ; DI CHIARA, 2005).

Outro conjunto de questões diz respeito ao papel desempenhado pelas redes sociais para transferência de informações e conhecimentos dentro de organizações. Krackhardt e Hanson (1997 apud MACEDO, 1999) declaram que as redes atuam como agrupamentos sociais formados por indivíduos com o objetivo de executar mais rapidamente as suas tarefas. 
Dessa forma, pode-se identificar a importância da transferência de informações e conhecimentos para a formação das redes sociais conforme a asserção de Tomaél, Alcará e Di Chiara (2005, p. 95):

[...] quanto mais informação trocamos com o ambiente que nos cerca, com os atores da nossa rede, maior será nossa bagagem de conhecimento, maior será o nosso estoque de informação, e é nesse poliedro de significados que inserimos as redes sociais.

Nesse sentido, Leonard (1998) comprova por meio de estudos sobre decisões gerenciais que, a maior parte das informações que embasam a tomada da decisão partem do contato humano direto, demonstrando a importância das redes sociais para procura e acesso de informações.

\subsubsection{Aprendizagem organizacional em redes sociais}

Tomaél, Alcará e Di Chiara (2005) afirmam que a inclusão em redes sociais é fundamental para o compartilhamento da informação e do conhecimento. Para as autoras, "as redes sociais constituem uma das estratégias subjacentes utilizadas pela sociedade para o compartilhamento da informação e do conhecimento, mediante as relações dos atores que as integram" (TOMAÉL; ALCARÁ; DI CHIARA, 2005, p. 93).

As redes sociais formadas dentro de organizações adquirem formas variadas, podendo atuar de maneira formal ou informal, dependendo dos interesses de seus integrantes.

O realce dado pela literatura ao processo de aprendizagem organizacional também proporcionou o desenvolvimento de pesquisas a respeito das redes formadas dentro de uma organização. Nessas circunstancias, Krackhardt e Hanson (1997 apud MACEDO, 1999) apresentam diferentes tipologias de redes informais nas organizações: redes de confiança (trust networks), que tratam de informações de natureza delicada; redes de trabalho ou de consulta (advice networks), que são a base para o acesso a informações técnicas necessárias ao trabalho por meio da estrutura informal; e redes de comunicação, que se baseia na troca regular de informações de trabalho, as chamadas "amizades de escritório". 
Choo (1998 apud TOMAÉL; ALCARÁ; DI CHIARA, 2005) observa ainda que as organizações utilizam a informação de duas formas. Inicialmente a informação é recolhida do meio e interpretada visando à construção de significados (sense making) e sua posterior retenção. No segundo modo de utilização, há a criação de novos conhecimentos (knowledge creation) por intermédio da sua transformação (tácito para explicito) e do compartilhamento da informação. Por fim, as empresas examinam as informações para chegar a uma decisão (decision making).

Nesta conjuntura, Lipnack e Stamps (1992, p. 19 apud MARTELETO, 2001, p. 72) levantam a seguinte proposição a respeito da importância das redes sociais na organização:

O que é novo no trabalho em redes de conexões é sua promessa como uma forma global de organização com raízes na participação individual. Uma forma que reconhece a independência enquanto apóia a interdependência. $O$ trabalho em redes de conexões pode conduzir a uma perspectiva global baseada na experiência pessoal.

Para Krogh, Ichijo e Nonaka (2001 apud TOMAÉL; ALCARÁ; DI CHIARA, 2005), as redes sociais contribuem para a transformação e o desenvolvimento do conhecimento dentro das organizações. Isto ocorre porque, "ao mesmo tempo em que contribuem para o aprimoramento dos ativos organizacionais, possibilitam que as organizações, distinguindo as características das redes e valendo-se delas, tornem o compartilhamento mais profícuo" (TOMAÉL; ALCARÁ; DI CHIARA, 2005, p. 94). 


\section{MÉTODOS E TÉCNICAS DE PESQUISA}

Este capítulo destrincha detalhadamente a metodologia de pesquisa utilizada no presente estudo, visando destacar a adequação dos meios escolhidos à consecução dos fins a que o trabalho se propõe.

"A metodologia tem interesse pelo estudo, descrição e análise dos métodos, lança esclarecimentos sobre os objetivos, utilidades e conseqüências ajudando-nos a compreender o próprio processo da Pesquisa Científica" (BARROS; LEHFELD, 1986 , p. 2). Dessa maneira, dispõe-se a seguir os métodos que direcionaram o trabalho na busca de seus objetivos.

\subsection{Delineamento da pesquisa}

O objetivo desta pesquisa é analisar como ocorre a aprendizagem informal necessária à atuação profissional. Dessa maneira, esta é uma pesquisa de nível descritivo, assim como definido por Gil (1999), quando fala que as pesquisas descritivas têm por objetivo, em primeira instância, descrever características de uma população ou fenômeno específico ou ainda estabelecer relações entre variáveis.

Para Cervo, Bervian e Silva (2007, p. 62), a pesquisa descritiva "busca conhecer as diversas situações e relações que ocorrem na vida social, política, econômica e demais aspectos do comportamento humano". Além disso, trata-se de uma pesquisa em que o pesquisador observa e então descreve o que observou, medindo e relatando as características de uma população ou fenômeno em estudo (BABBIE, 1989).

Quanto à composição da pesquisa, optou-se pela metodologia conhecida como estudo de caso. Para Yin (2006), o estudo de caso é um dos caminhos para a realização de pesquisa de ciência social. Normalmente, estudos de caso são as estratégias preferidas quando se busca responder questões "como" ou "por que", quando o investigador tem um pequeno controle sobre os eventos, e quando o foco é no fenômeno contemporâneo entre alguns contextos na vida real.

Ainda segundo Yin (2006), o estudo de caso e os experimentos não representam uma "prova", e o objetivo do investigador é expandir e generalizar (generalização analítica) e não enumerar freqüências (generalização estatística). 
Mais que isso, por se tratar de uma pesquisa na qual serão identificados os processos por meio dos quais ocorre a aprendizagem informal, se caracteriza como uma pesquisa qualitativa, que, segundo Richardson (1999), descreve a complexidade de um problema em especial, analisa a relação de variáveis, compreende e classifica situações vividas por grupos sociais, contribuem nos processos de mudança e ainda possibilita o entendimento de comportamentos específicos de indivíduos.

Ainda nesse contexto Neves (1996, p. 1) afirma que a pesquisa qualitativa "costuma ser direcionada ao longo de seu desenvolvimento; além disso, não busca enumerar ou medir eventos e, geralmente, não emprega instrumental estatístico para análise de dados".

\subsection{Caracterização da organização objeto de estudo}

O estudo foi realizado no Ministério das Relações Exteriores, órgão público do Poder Executivo criado em 16 de março de 1908 e responsável por assessorar o Presidente da República na formulação e execução da política externa brasileira.

O Itamaraty, nome pelo qual o Ministério é popularmente conhecido, atua sobre inúmeras vertentes: política, comercial, econômica, financeira, cultural e consular das relações externas, áreas nas quais exerce as tarefas clássicas da diplomacia (MRE, 2009a).

A sede atual do Ministério é o Palácio dos Arcos, localizado em Brasília. Entretanto, o órgão conta com uma estrutura no Brasil que inclui sua antiga sede, o Palácio Itamaraty no Rio de Janeiro e Escritórios de Representação Regional em Porto Alegre, Florianópolis, Curitiba, Belo Horizonte, São Paulo, Recife e Manaus. Além disso, conta com uma entidade vinculada, a Fundação Alexandre de Gusmão (Funag), seu braço acadêmico, além do Instituto Rio Branco, encarregado do recrutamento e treinamento de diplomatas (MRE, 2009a).

No exterior, a organização possui cerca de 210 postos, subdivididos em: Embaixadas, Missões/Delegações junto a organismos internacionais, ConsuladosGerais, Consulados, e Vice-Consulados (MRE, 2009a). 
Os funcionários pertencentes ao Serviço Exterior Brasileiro se distribuem em três carreiras: a carreira diplomática e as carreiras de Oficial de Chancelaria e de Assistente de Chancelaria. Atualmente o Ministério conta com 2.930 servidores da carreira em exercício no Brasil e no exterior, distribuídos de acordo com a Tabela 1.

É importante ressaltar que outros funcionários integram o quadro do Ministério, porém apenas estes três cargos são próprios do Serviço Exterior Brasileiro.

Tabela 1. Número total de servidores ativos no Brasil e no Exterior

\begin{tabular}{|c|c|}
\hline Carreira & Quantidade Total de Servidores Ativos em 28/04/2009 \\
\hline Assistente de Chancelaria & 742 \\
\hline Diplomata & 1.387 \\
\hline Oficial de Chancelaria & 801 \\
\hline Total & 2.930 \\
\hline
\end{tabular}

Fonte: Sistema de Gestão de Recursos Humanos do MRE.

O ingresso na carreira diplomática ocorre por concurso público de nível superior realizado pelo Instituto Rio Branco. Para as carreiras de Oficial de Chancelaria e de Assistente de Chancelaria, o ingresso também ocorre por meio de concurso público de nível superior e nível médio, respectivamente.

O estudo de caso foi realizado exclusivamente com integrantes da carreira de Assistente de Chancelaria, criada por meio da Lei 8.829, de 22 de dezembro de 1993. O Decreto $1.565 / 95$ regulamentou essa carreira e a Portaria Interministerial número 5, de 18 de agosto de 1995, aprovou suas atribuições.

As competências destes servidores, conforme definido em lei, são as seguintes:

a) prestar apoio administrativo aos servidores da Carreira de Diplomata, abrangendo tarefas de secretariado, taquigrafia, datilografia, processamento de dados, inclusive de textos técnicos em idioma estrangeiro; 
b) executar serviços de apoio administrativo em tarefas peculiares ao Ministério das Relações Exteriores, tais como aqueles relacionados com atividades de cerimonial, prática consular, acordos e atos internacionais, difusão e cooperação cultural, cooperação técnica e promoção comercial;

c) executar outras tarefas administrativas de nível médio na Secretaria de Estado das Relações Exteriores, nas Missões Diplomáticas e Repartições Consulares.

Atualmente, o ltamaraty trata de diversas questões de necessidade interna e repercussão externa, tais como: proteção ao meio ambiente, estímulo à ciência e tecnologia e assistência humanitária. Sua atuação busca a satisfação de interesses nacionais com a colaboração de outras nações (MRE, 2009).

\subsection{Descrição das variáveis de pesquisa}

A pesquisa buscou identificar de que maneira ocorre a aprendizagem informal necessária à atuação profissional. Para isso, a entrevista foi estruturada considerando três variáveis básicas de pesquisa e suas relações com a aprendizagem informal: desenvolvimento de competências, processos de aprendizagem e redes sociais.

As perguntas foram formuladas com o objetivo de identificar valores, concepções, idéias ou referenciais simbólicos, buscando compreender as concepções de aprendizagem de cada participante. Além disso, buscou-se, por meio dos dados obtidos, configurar algum nível de generalização no que dizia respeito aos processos de aprendizagem.

\subsection{População e amostra}

De acordo com Barros e Lehfeld (1986, p. 104), as pesquisas são realizadas por meio de amostras, pois "nem sempre é possível obter as informações de todos os indivíduos ou elementos que compõe o universo ou a população que se deseja estudar".

A presente pesquisa foi realizada com ocupantes do cargo de Assistente de Chancelaria residentes em Brasília e lotados na Secretaria de Estado. Foram 
considerados, no universo total de 742 Assistentes de Chancelaria possíveis participantes, dois grupos específicos formados por assistentes empossados em momentos distintos: no ano de 2005 e no ano de 2008.

Para delimitar a amostra, foi necessário analisar, dentro destes conjuntos, os servidores que ainda permaneciam no Ministério, desconsiderando servidores desligados ou removidos para postos no exterior. Todos os dados em questão encontram-se dispostos na Tabela 2.

Tabela 2. Comparativo dos Assistentes de Chancelaria empossados em 2008 e 2005

\begin{tabular}{|c|c|c|c|c|}
\hline Ano & Admissões & Desligamentos & Total de Ativos & No Brasil \\
\hline 2008 & 100 & 14 & 86 & 86 \\
\hline 2005 & 72 & 25 & 47 & 35 \\
\hline
\end{tabular}

Fonte: Sistema de Gestão de Recursos Humanos do MRE.

Para a realização das entrevistas, os participantes foram selecionados por meio de amostra probabilística casual sistemática, em que a população estava ordenada de tal forma de modo que cada elemento identificou-se por sua colocação ou posição. Para Barros e Lehfeld (1986, p. 106), neste tipo de amostra "a seleção é realizada com base num processo que dá a cada membro da população a mesma probabilidade de ser incluído na amostra".

Dessa maneira, foram selecionados aleatoriamente seis integrantes de cada agrupamento lotados no Brasil. Estes servidores foram contatados por correio eletrônico e convidados a participar do estudo de caso.

Para facilitar a análise dos dados, considerar-se-á como Grupo A o grupo formado pelos Assistentes de Chancelaria empossados em 2005, e como Grupo B o formado pelos funcionários empossados em 2008.

O grupo A foi formado por quatro mulheres e dois homens, enquanto no grupo $B$, o trabalho foi realizado com três mulheres e três homens. As Tabelas 3 e 4 ilustram os dados sócio-demográficos e funcionais de cada membro participante desta pesquisa. Registre-se que o organograma do Órgão encontra-se no Anexo A deste trabalho, permitindo assim a visualização das lotações expostas nas Tabelas 3 e 4. 
É importante ressaltar que todos os membros do grupo A possuem o mesmo tempo de serviço no Ministério: quatro anos. Da mesma maneira, todos os integrantes do grupo B possuíam, na data de realização das entrevistas, oito meses de tempo de serviço no Itamaraty.

Tabela 3. Dados do Grupo A - Assistentes de Chancelaria empossados em 2005

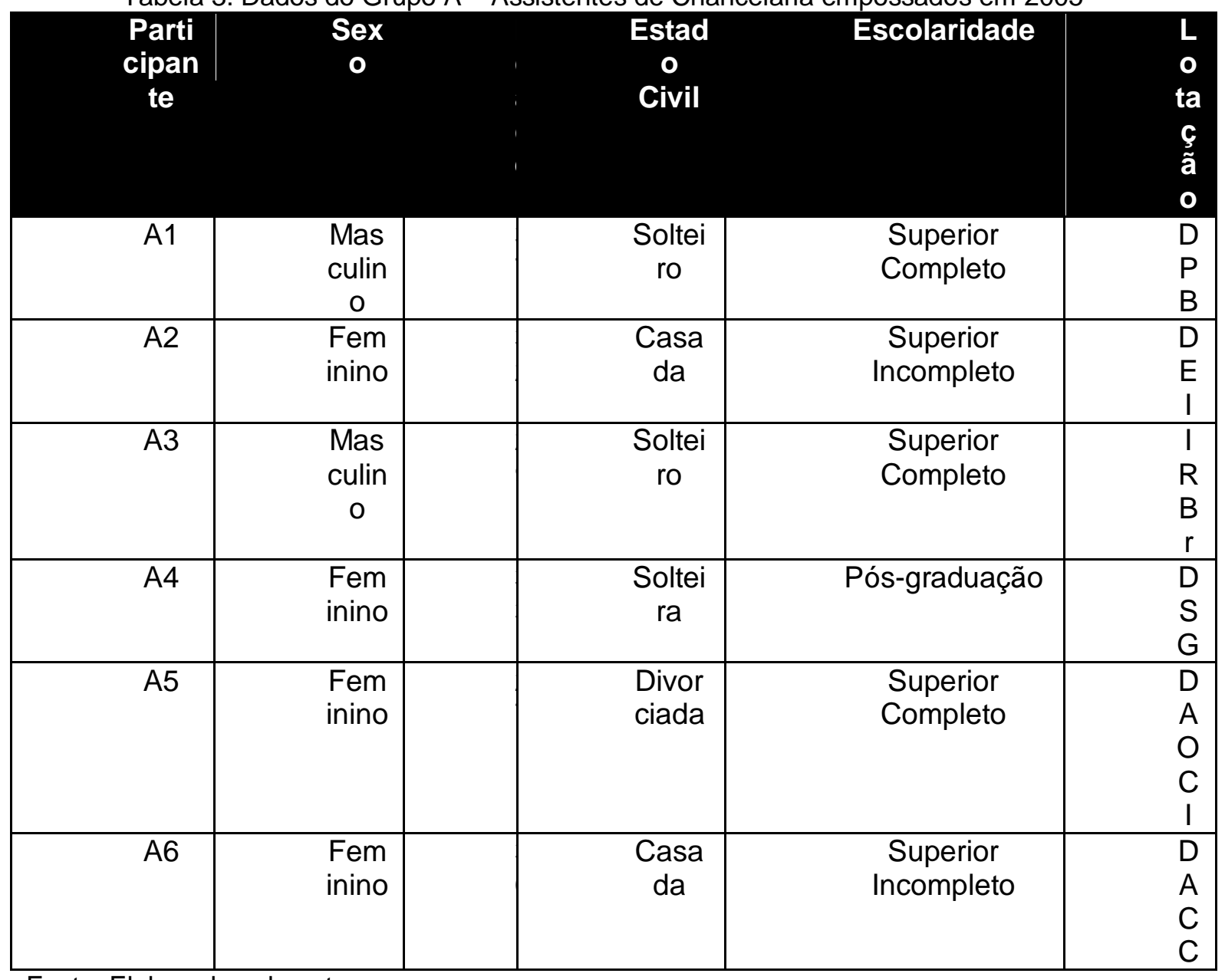

Fonte: Elaborado pela autora.

Tabela 4. Dados do Grupo B - Assistentes de Chancelaria empossados em 2008

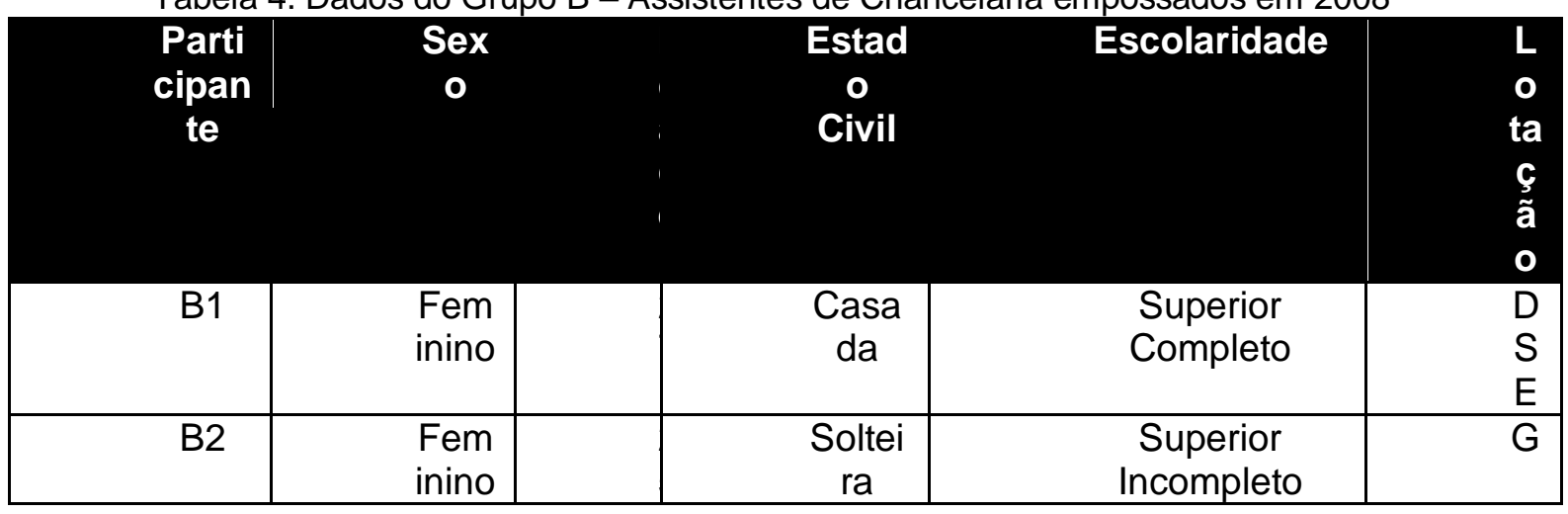




\begin{tabular}{|c|c|c|c|c|}
\hline B3 & $\begin{array}{c}\text { Mas } \\
\text { culin } \\
0\end{array}$ & $\begin{array}{l}\text { Soltei } \\
\text { ro }\end{array}$ & $\begin{array}{l}\text { Superior } \\
\text { Incompleto }\end{array}$ & $\begin{array}{l}\mathrm{D} \\
\mathrm{P}\end{array}$ \\
\hline B4 & $\begin{array}{l}\text { Fem } \\
\text { inino }\end{array}$ & $\begin{array}{c}\text { Soltei } \\
\text { ra }\end{array}$ & $\begin{array}{l}\text { Superior } \\
\text { Completo }\end{array}$ & $\begin{array}{l}\text { S } \\
\text { C } \\
L\end{array}$ \\
\hline B5 & $\begin{array}{c}\text { Mas } \\
\text { culin } \\
0\end{array}$ & $\begin{array}{c}\text { Soltei } \\
\text { ro }\end{array}$ & $\begin{array}{c}\text { Superior } \\
\text { Incompleto }\end{array}$ & $\begin{array}{l}\mathrm{D} \\
\mathrm{P} \\
\mathrm{A} \\
\mathrm{G}\end{array}$ \\
\hline B6 & $\begin{array}{c}\text { Mas } \\
\text { culin } \\
0\end{array}$ & $\begin{array}{l}\text { Soltei } \\
\text { ro }\end{array}$ & $\begin{array}{c}\text { Superior } \\
\text { Incompleto }\end{array}$ & C \\
\hline
\end{tabular}

Fonte: Elaborado pela autora.

Para $\circ$ grupo A da pesquisa foram realizadas perguntas específicas, relativas à possibilidade de trabalho no exterior. É necessário ressaltar que essas questões foram direcionadas exclusivamente a este grupo pelo fato de haver normas no Ministério com relação à remoção para Postos no exterior. Os Assistentes de Chancelaria com dois ou mais anos de exercício na Secretaria de Estado podem se candidatar ao Plano de Remoções, processo que ocorre semestralmente e que provoca alterações nas lotações dos Postos no exterior (Consulados, Embaixadas e Missões Diplomáticas) e na Secretaria de Estado. Dessa maneira, como os funcionários do Grupo B possuem apenas oito meses de exercício, não estão aptos a participar do Plano e não poderiam, assim, contribuir com respostas a esses questionamentos.

No grupo $A$, apenas três dos seis servidores entrevistados tiveram a oportunidade de trabalhar no Exterior, conforme explicitado na Tabela 5.

Tabela 5. Servidores do Grupo A que trabalharam no exterior

\section{\begin{tabular}{l|l|l} 
Participante & Tempo de serviço no Exterior & Lotação
\end{tabular}}

\begin{tabular}{|l|l|l|}
\hline A2 & 2 (dois) anos & Consulado-Geral em Montreal \\
\hline A3 & 2 (dois) meses & Embaixada em Taiwan \\
\hline A6 & 6 (seis) meses & Vice-Consulado em Cobija \\
\hline
\end{tabular}

Fonte: Elaborado pela autora. 


\subsection{Procedimentos e instrumentos utilizados na coleta e análise dos dados}

Para Yin (2006) quando uma pesquisa é sobre uma organização, como e por que ela funciona, sua fonte de dados deve ser os indivíduos que nela atuam.

Ainda de acordo com Yin (2006), os dados advindos de um estudo de caso podem vir de seis fontes diferentes: documentos, registros em arquivos, entrevistas, observação direta, observação participante e artefatos físicos. Para a realização deste estudo de caso será necessária a utilização de três dessas seis fontes: documentação, registros em arquivo e, principalmente, entrevistas.

Para expressar melhor essa idéia, considera-se que documentação tem função de "corroborar e valorizar as evidências oriundas de outras fontes" (YIN, 2005, p.112), podendo ser utilizada até mesmo para a verificação de grafia de nomes ou siglas. Já os registros em arquivo podem ser utilizados "em conjunto com outras fontes de informação ao se produzir um estudo de caso" (YIN, 2005, p. 116). Como exemplo deste tipo de material, pode-se citar os dados retirados do Sistema de Gestão de Recursos Humanos do Ministério, que permitiu verificar quais funcionários ainda faziam parte do quadro permanente e residiam no Brasil no momento de realização da pesquisa. Por fim, as entrevistas "constituem uma fonte essencial de evidencias para o estudo de caso, já que a maioria delas trata de questões humanas" (YIN, 2005, p. 118).

Fonte principal de informação, as entrevistas semi-estruturadas foram efetuadas com uma amostra de seis participantes de cada grupo (ocupantes do cargo de Assistente de Chancelaria empossados em períodos distintos) escolhidos aleatoriamente e contatados por meio do correio eletrônico.

Após o contato inicial por e-mail, os servidores contatados marcaram 0 horário para a realização das entrevistas conforme suas preferências pessoais. $O$ processo se deu através de contato direto entre o entrevistador e os entrevistados, com duração média de 25 minutos para cada entrevista.

O roteiro referente às entrevistas realizadas encontra-se disposto no Apêndice A deste trabalho. É importante ressaltar que todas as entrevistas foram gravadas e posteriormente, transcritas, para que seu conteúdo fosse analisado. 
O processo de análise de dados baseou-se no conjunto de técnicas conhecido como análise de conteúdo. Para Roesch (2007, p. 169), a análise de conteúdo tem o "propósito de contar a freqüência de um fenômeno e procurar identificar as relações entre os fenômenos, sendo que a interpretação dos dados se apóia em modelos conceituais definidos a priori'. De acordo com Weber (1990 apud ROESCH, 2007), a análise de conteúdo usa uma série de procedimentos para suscitar deduções válidas a partir de um texto, ou seja, no caso específico desta pesquisa, conceber inferências a partir das transcrições das entrevistas.

Durante a análise dos dados, a utilização de transcrições de falas dos próprios entrevistados "permite captar o nível de emoção dos respondentes, a maneira como organizam o mundo, seus pensamentos sobre o que está acontecendo, suas experiências e percepções básicas" (ROESCH, 2007, p. 169)

\subsection{Período de realização da pesquisa}

As entrevistas com os funcionários do Ministério das Relações Exteriores foram realizadas durante a última semana de maio e a primeira semana de junho do ano de 2009, mais especificamente, do dia 25 de maio ao dia 5 de junho de 2009, durante o horário do expediente (de 9 às 19h), conforme fosse mais conveniente ao entrevistado.

\subsection{Comentários sobre o processo da coleta de dados}

Os dados desta pesquisa foram obtidos por meio de entrevistas semiestruturadas, realizadas com dois grupos distintos de seis participantes cada. $O$ Grupo A era formado por funcionários admitidos em 2005 e o Grupo B, por sua vez, era composto por funcionários admitidos em 2008.

Todas as entrevistas foram realizadas durante o horário do expediente, no próprio Ministério das Relações Exteriores, que se localiza em Brasília, D.F., e está situado no seguinte endereço: Esplanada dos Ministérios, Bloco $\mathrm{H}$.

Os depoimentos dos entrevistados foram gravados e transcritos, para facilitar a análise dos dados. Além disso, foram produzidos quadros com o auxílio do 
programa Microsoft Excel, visando a vinculação dos principais dados, obtidos por meio do resumo de cada resposta dada. O objetivo dessa etapa foi facilitar o processo de compilação dos dados e análise de conteúdo.

\section{APRESENTAÇÃO E ANÁLISE DOS RESULTADOS DA PESQUISA}

\subsection{Grupo A}




\subsubsection{Desenvolvimento de competências}

Com base nas entrevistas realizadas, verificou-se que os integrantes do grupo A citaram diversas competências necessárias para a realização de suas tarefas, conforme disposto no Quadro 1.

Dentre elas, convém destacar a disciplina e a concentração, identificadas por vários membros da equipe como essenciais para a realização de um trabalho bem feito. Além dessas, percebe-se a influência de outras competências como: próatividade, cooperação, bom domínio do português e de línguas estrangeiras, cordialidade, gestão de equipes, iniciativa, conhecimentos de matemática e de informática. Para ilustrar esses dados, seguem transcrições de afirmativas dos servidores A4, A1 e A3:

\footnotetext{
"Acredito que no meu trabalho é importante ter muita paciência e muito jogo de cintura para resolver as coisas inesperadas que acontecem todos os dias. Lidar com o público também exige muita paciência, muita tolerância, saber ouvir, capacidade de pensar rápido para dar uma solução para os problemas (A4)."

"Para mim é muito importante ser disciplinado, principalmente em relação à horários, além de bom domínio da língua portuguesa e fluência em língua estrangeira (A1)."

"Aqui na minha Divisão eu preciso cooperar com todos. A tarefa que eu executo aqui repercute no trabalho de outro colega mais na frente, então estamos sempre conversando, trocando informações, até para adiantar os casos que ainda estão por vir. Assim todo mundo se ajuda (A3)."
}

Os membros desse grupo atribuíram a diversos fatores o desenvolvimento destas competências. Dois funcionários alegaram que o desenvolvimento ocorreu fora do ambiente de trabalho, em situações da sua vida privada ou até mesmo na criação que receberam dos pais. Outros dois servidores afirmaram que desenvolveram tais competências por meio de cursos ou treinamentos específicos, principalmente no caso de conhecimentos de informática e de outras línguas. Vale ressaltar que o Ministério possui um convênio com as principais escolas de línguas de Brasília, permitindo que os funcionários realizem cursos de línguas como inglês, francês, alemão, árabe e chinês no próprio Ministério, durante o horário do expediente e sem custos para os servidores. 
Porém, no caso mais importante para esta pesquisa, que foca nos processos de aprendizagem informal, o servidor A4 afirma que o desenvolvimento se deu com o passar do tempo, por meio da repetição das tarefas:

"Com o dia a dia, à medida que vai passando o tempo, você vai se sentindo mais seguro, aí já sabe passar uma resposta, a solução adequada para cada tipo de problema. Os problemas vão se repetindo e aí você aprende como lidar com eles mais facilmente."

Quadro 1. Desenvolvimento de competências, de acordo com respondentes do grupo A

\begin{tabular}{|c|c|c|c|c|c|}
\hline Membro & $\begin{array}{l}\text { Competências } \\
\text { Necessárias }\end{array}$ & $\begin{array}{c}\text { Como as } \\
\text { competências } \\
\text { foram } \\
\text { adquiridas }\end{array}$ & $\begin{array}{c}\text { Principais } \\
\text { desafios } \\
\text { enfrentados }\end{array}$ & $\begin{array}{c}\text { Enfrentamento } \\
\text { dos desafios }\end{array}$ & $\begin{array}{l}\text { Competências } \\
\text { desenvolvidas }\end{array}$ \\
\hline A1 & $\begin{array}{l}\text { Concentração, } \\
\text { iniciativa, } \\
\text { cordialidade e } \\
\text { fluência em } \\
\text { inglês. }\end{array}$ & $\begin{array}{l}\text { A partir de } \\
\text { experiências } \\
\text { pessoais, } \\
\text { criação dos } \\
\text { pais. }\end{array}$ & $\begin{array}{c}\text { Adaptação à } \\
\text { cultura } \\
\text { hierarquizada e } \\
\text { ao serviço } \\
\text { público. }\end{array}$ & $\begin{array}{c}\text { Compreensão } \\
\text { da cultura da } \\
\text { casa. }\end{array}$ & $\begin{array}{c}\text { A flexibilidade } \\
\text { e aceitação. }\end{array}$ \\
\hline $\mathbf{A 2}$ & $\begin{array}{l}\text { Pró-atividade, } \\
\text { gestão de } \\
\text { equipes e boa } \\
\text { redação. }\end{array}$ & $\begin{array}{l}\text { Com a própria } \\
\text { experiência } \\
\text { profissional e } \\
\text { treinamentos } \\
\text { no Ministério. }\end{array}$ & $\begin{array}{c}\text { Cultura } \\
\text { organizacional, } \\
\text { hierarquia. }\end{array}$ & $\begin{array}{c}\text { Não houve } \\
\text { opção, foi } \\
\text { necessário se } \\
\text { adaptar. }\end{array}$ & Aceitação. \\
\hline $\mathbf{A 3}$ & $\begin{array}{l}\text { Saber lidar com a } \\
\text { pressão, ser } \\
\text { cooperativo. }\end{array}$ & $\begin{array}{l}\text { Por meio de } \\
\text { observação, } \\
\text { indicação de } \\
\text { colegas e } \\
\text { aprendendo } \\
\text { por mim } \\
\text { mesmo. }\end{array}$ & $\begin{array}{c}\text { Pressão por } \\
\text { parte da chefia. }\end{array}$ & $\begin{array}{c}\text { Orientação de } \\
\text { colegas acerca } \\
\text { da maneira } \\
\text { correta de } \\
\text { executar os } \\
\text { processos }\end{array}$ & $\begin{array}{c}\text { Especialmente } \\
\text { trabalho em } \\
\text { equipe. }\end{array}$ \\
\hline A4 & $\begin{array}{l}\text { Legislação, } \\
\text { Tolerância, saber } \\
\text { lidar com o } \\
\text { público. }\end{array}$ & $\begin{array}{l}\text { Com o tempo } \\
\text { de serviço. }\end{array}$ & $\begin{array}{c}\text { Hierarquia no } \\
\text { Ministério. }\end{array}$ & $\begin{array}{l}\text { Aceitação, } \\
\text { adaptação. }\end{array}$ & $\begin{array}{l}\text { Flexibilidade, } \\
\text { adaptação, } \\
\text { tolerância. }\end{array}$ \\
\hline $\mathbf{A 5}$ & $\begin{array}{c}\text { Respeito, } \\
\text { simpatia, } \\
\text { conhecimentos } \\
\text { de informática e } \\
\text { de legislação. }\end{array}$ & $\begin{array}{l}\text { Lidando com o } \\
\text { público todos } \\
\text { os dias, com a } \\
\text { prática e com } \\
\text { cursos. }\end{array}$ & $\begin{array}{l}\text { Problemas } \\
\text { relacionados à } \\
\text { estrutura do } \\
\text { Ministério. }\end{array}$ & $\begin{array}{c}\text { Compreensão } \\
\text { dos valores da } \\
\text { organização. }\end{array}$ & $\begin{array}{l}\text { Tolerância, } \\
\text { adaptação. }\end{array}$ \\
\hline A6 & $\begin{array}{l}\text { Português, } \\
\text { legislação, pró- } \\
\text { atividade e } \\
\text { iniciativa. }\end{array}$ & $\begin{array}{c}\text { Cursos, } \\
\text { faculdade, na } \\
\text { vida particular. }\end{array}$ & $\begin{array}{l}\text { Administrar o } \\
\text { tempo e a } \\
\text { quantidade de } \\
\text { serviço. }\end{array}$ & $\begin{array}{c}\text { Planejamento } \\
\text { das tarefas, } \\
\text { utilizando } \\
\text { agendas e } \\
\text { lembretes do } \\
\text { Outlook. }\end{array}$ & $\begin{array}{l}\text { Organização, } \\
\text { planejamento. }\end{array}$ \\
\hline
\end{tabular}

Fonte: Elaborado pela autora.

Com relação aos desafios enfrentados por este grupo de funcionários, o interessante é que quatro servidores citaram problemas relacionados à cultura do 
Ministério. O Itamaraty possui uma estrutura altamente hierárquica, em que a disciplina é bastante valorizada. É uma organização com fortes tradições e valores comparados aos de organizações militares, muito provavelmente devido ao fato histórico de que o Ministério foi criado com o auxílio e participação ativa do Exército em 1908. Para ilustrar essa afirmação, seguem afirmações dos servidores A2, A4 e A5:

"Acho que foi entender essa hierarquia que tem aqui dentro. Tipo assim (sic), se um cara está em um grau muito alto da carreira, é Embaixador, às vezes você tem que fazer coisas que você não faria para uma pessoa que está em um grau inferior. Isso é uma cultura do Ministério e engolir isso foi difícil. Ainda é, mas com o tempo você vai se anestesiando (A2)."

"A chefia é aqui é muito rígida e a hierarquia muito estabelecida muitas vezes dificulta a comunicação com superiores (A4)."

"Os problemas em relação à hierarquia institucional são enfrentados por todos da minha classe e já estão bastante enraizados na cultura do Ministério (A5)."

Os meios encontrados pelos servidores para o enfrentamento desses desafios foram o desenvolvimento de competências como a flexibilidade, a paciência e a aceitação às normas do ambiente. O servidor A4 afirma que "sempre vai haver uma pessoa superior, um chefe ou sei lá quem a quem você vai ter que prestar obediência e tudo mais. Faço o trabalho sem dar a importância que eu dava antigamente."

\subsubsection{Processos de aprendizagem}

Ao analisar os pontos da entrevista que tratam dos processos de aprendizagem, ordenados resumidamente no Quadro 2, percebe-se que os entrevistados são unânimes em responder que, em caso de dúvida recorrem, em primeiro lugar, a colegas mais antigos no setor. É interessante a informação do servidor A5, que afirma: "Sempre procuro os meus colegas porque geralmente eles sabem mais do que a própria chefia. É muito mais comum os chefes nos procurarem." De maneira distinta, o servidor A1 afirma que costuma confirmar as informações que recebe de colegas com os chefes, para ter mais segurança durante a realização do trabalho. 
Em um segundo momento, os funcionários buscam informações na legislação, em manuais ou mesmo com os próprios chefes. Além disso, todos consideram que estão aptos a ajudar outros colegas, sendo que alguns inclusive treinaram novos funcionários do setor. Esse fato caracteriza a forte influência dos processos informais de aprendizagem.

Quadro 2. Processos de aprendizagem, de acordo com respondentes do grupo A

\begin{tabular}{|c|c|c|}
\hline Entrevistado & $\begin{array}{l}\text { A quem recorre em caso de } \\
\text { dúvida }\end{array}$ & É procurado em caso de dúvida? \\
\hline A1 & $\begin{array}{l}\text { Recorro aos colegas da equipe e à } \\
\text { chefia simultaneamente para ter } \\
\text { segurança. }\end{array}$ & Muito. \\
\hline A2 & $\begin{array}{l}\text { Aos colegas, à legislação e à chefia, } \\
\text { apenas em último caso, em dúvidas } \\
\text { que precisam de uma orientação } \\
\text { bastante específica. }\end{array}$ & $\begin{array}{l}\text { Sim, muitas vezes, porque sabem que } \\
\text { eu costumo estar por dentro da } \\
\text { legislação também porque } \\
\text { desenvolvemos nossas atividades de } \\
\text { forma cooperativa. }\end{array}$ \\
\hline A3 & À minha colega de sala. & Sim. \\
\hline A4 & Recorro aos colegas mais antigos. & Às vezes sim. \\
\hline A5 & $\begin{array}{l}\text { Aos colegas na maioria das vezes. } \\
\text { Eles geralmente sabem mais do que } \\
\text { a chefia. }\end{array}$ & Sim, com freqüência. \\
\hline A6 & $\begin{array}{c}\text { Aos colegas de trabalho e a manuais } \\
\text { que existem no meu setor. }\end{array}$ & Sim. \\
\hline
\end{tabular}

\subsubsection{Redes sociais}

Os funcionários afirmam, ainda, que conseguiram transferir seus conhecimentos por meio conversas informais, reuniões e por meio da observação. funcionário A2 declarou que treinou um novo colega "como se fosse uma aula particular mesmo. Eu disse 'senta aqui do lado que eu vou te mostrar como é que faz'." Exemplificando outro ponto de vista sobre a mesma questão, o servidor A4, 
chefe de uma equipe de três integrantes, sustenta que "nós da equipe discutimos o nosso trabalho e trocamos informações por meio de reuniões freqüentes."

Quadro 3. Redes sociais, de acordo com respondentes do grupo A

\begin{tabular}{|c|c|}
\hline Entrevistado & Repassou seus conhecimentos para outros colegas? Como? \\
\hline A1 & Sim, com conversas, troca de informações e reuniões. \\
\hline $\mathbf{A 2}$ & $\begin{array}{l}\text { Sim, pois como trabalhamos com a elaboração de normativos internos, sendo } \\
\text { a natureza do nosso trabalho passar informações, ainda chefio uma equipe } \\
\text { com três integrantes. Nós discutimos o nosso trabalho e trocamos } \\
\text { informações por meio de reuniões freqüentes. }\end{array}$ \\
\hline $\mathbf{A 3}$ & $\begin{array}{l}\text { Explicando e exemplificando as situações que normalmente ocorrem, o } \\
\text { caminho a ser seguido em cada atividade. }\end{array}$ \\
\hline A4 & $\begin{array}{l}\text { Como se fosse uma aula particular mesmo. Senta aqui do lado que eu } \\
\text { vou te mostrar, é assim, é assim e anota. }\end{array}$ \\
\hline A5 & $\begin{array}{l}\text { Conversando, explicando, exemplificando, tirando dúvidas. É importante estar } \\
\text { disponível para os colegas e ter boa vontade de ensinar. }\end{array}$ \\
\hline A6 & $\begin{array}{l}\text { Eu mostro como faz, depois deixo a pessoa fazer e observo. Aí mostro aonde } \\
\text { está certo, aonde está errado. E deixo praticar. A prática solidifica o que foi } \\
\text { ensinado. }\end{array}$ \\
\hline
\end{tabular}

Fonte: Elaborado pela autora.

\subsubsection{Desenvolvimento de competências por meio de experiência de trabalho no exterior}

Com relação aos desafios enfrentados por estes três funcionários, percebemos que cada um teve uma perspectiva diferente. O servidor A3 considerou um problema "o choque cultural, porque a cultura era totalmente diferente, além da língua e da comunicação". Outra questão levantada pelo entrevistado A2 foi o horário do trabalho. Ele afirma que "havia plantões nos fins de semana e eu não estava acostumado com isso." Já para o funcionário A6, o principal desafio foi "o desenvolvimento de uma nova atividade diversa da que eu executava no Brasil. Fui trabalhar em um posto com somente dois funcionários e nós tínhamos que desempenhar diversos papéis". 
Quadro 4. Experiências de trabalho no exterior, de acordo com respondentes do grupo A

\begin{tabular}{|c|c|c|c|c|}
\hline Entrevistado & $\begin{array}{l}\text { Morou/Trabalhou } \\
\text { no Exterior }\end{array}$ & Principais Desafios & $\begin{array}{c}\text { Enfrentamento } \\
\text { dos desafios }\end{array}$ & $\begin{array}{l}\text { Competências } \\
\text { desenvolvidas }\end{array}$ \\
\hline $\mathbf{A 2}$ & Sim. & $\begin{array}{l}\text { Plantões, horário do } \\
\text { expediente diferente. }\end{array}$ & $\begin{array}{l}\text { Dedicação ao } \\
\text { trabalho, } \\
\text { adaptação. }\end{array}$ & $\begin{array}{c}\text { Maior } \\
\text { conhecimento dos } \\
\text { processos e } \\
\text { domínio da língua. }\end{array}$ \\
\hline A3 & Sim. & $\begin{array}{l}\text { Choque cultural, } \\
\text { comunicação. }\end{array}$ & Tolerância. & $\begin{array}{c}\text { Maior } \\
\text { conhecimento dos } \\
\text { processos e do } \\
\text { funcionamento do } \\
\text { Ministério. }\end{array}$ \\
\hline A6 & Sim. & $\begin{array}{l}\text { Atividades diferentes, } \\
\text { Posto pequeno, poucos } \\
\text { funcionários. }\end{array}$ & $\begin{array}{l}\text { Dedicação ao } \\
\text { trabalho. }\end{array}$ & $\begin{array}{c}\text { Flexibilidade, } \\
\text { fluência em língua } \\
\text { estrangeira. }\end{array}$ \\
\hline
\end{tabular}

Fonte: Elaborado pela autora.

Diversas maneiras foram encontradas para superar estes desafios. O servidor A3 considera que foi preciso ter "tolerância à ambigüidade, ou seja, compreender que há locais em que as pessoas pensam e agem de uma maneira diferente da sua." Já para os funcionários $A 2$ e $A 3$, a dedicação foi o caminho encontrado na busca pela superação, conforme os depoimentos abaixo:

"Dedicação exclusiva. Dediquei-me bastante à prática do idioma, pois precisava redigir documentos e me adaptei a rotina dos plantões após alguns meses. Quando voltei, até estranhei os finais de semana livres (A2)."

"Me esforcei (sic) bastante, entrando em contato com outros colegas em busca de informações. No início foi um pouco aflitivo, mas quando comecei a dominar os processos ficou mais tranqüilo (A6)."

Essas experiências possibilitaram que estes servidores desenvolvessem outras competências, que facilitam a realização das atividades executadas no Brasil. O essencial, para os participantes A3 e A2, foi entender o funcionamento de um Posto no exterior. É importante ressaltar que a Secretaria de Estado e os Postos trabalham de forma interligada, sendo que muitas decisões passam por funcionários lotados no Brasil, conforme se pode depreender das transcrições abaixo: 
"Antes de eu ir, quando a gente falava de setores como comunicações, contabilidade, mala diplomática, essas coisas, ficava tudo uma noção muito abstrata, eu não sabia muito bem do que eles estavam falando. Quando você vai lá e vive o dia a dia você aprende a dinâmica da coisa, aí é melhor por isso, você fica mais integrado ao trabalho (A3)."

"Além da fluência no espanhol, acho que o mais importante é que você passa a entender melhor como funciona o Ministério, passa a entender a importância que as coisas que você faz aqui têm lá fora. Você vê que tudo está ligado (A2)."

Já para o servidor A6, as principais competências adquiridas foram a flexibilidade, necessária para o desempenho de diversas tarefas, além da a fluência na língua local. Acrescenta, ainda, que fez novas amizades e que aprendeu a respeito da cultura e dos costumes locais.

\subsection{Grupo B}

\subsubsection{Desenvolvimento de competências}

Os dados retirados das entrevistas do Grupo B, formado por Assistentes de Chancelaria empossados em 2008, mostram, sob uma nova perspectiva, a visão destes funcionários sobre o objeto de pesquisa deste trabalho. Os principais pontos abordados durante as entrevistas estão dispostos no Quadro 5.

Para os integrantes do grupo $\mathrm{B}$, as competências necessárias citadas para a realização de suas tarefas são: iniciativa, responsabilidade, comprometimento, além da paciência e da disciplina, citadas com veemência pelo grupo A. Os entrevistados adicionaram ainda conhecimentos de informática, português e matemática, além de sistemas específicos de cada setor, como por exemplo, o Sistema Integrado de Administração de Recursos Humanos - SIAPE.

Quadro 5. Desenvolvimento de competências, de acordo com respondentes do Grupo B 


\begin{tabular}{|c|c|c|c|c|c|}
\hline & & $\begin{array}{c}\text { foram } \\
\text { adquiridas }\end{array}$ & enfrentados & & \\
\hline B1 & $\begin{array}{l}\text { Conhecimentos } \\
\text { em informática, } \\
\text { atendimento ao } \\
\text { público e } \\
\text { disciplina. }\end{array}$ & $\begin{array}{l}\text { Em outras } \\
\text { experiências } \\
\text { de trabalho }\end{array}$ & $\begin{array}{c}\text { Sempre } \\
\text { trabalhei em } \\
\text { empresas } \\
\text { privadas e aqui } \\
\text { no serviço } \\
\text { público é } \\
\text { diferente }\end{array}$ & $\begin{array}{l}\text { Por meio da } \\
\text { adaptação. }\end{array}$ & $\begin{array}{l}\text { Tolerância, } \\
\text { flexibilidade. }\end{array}$ \\
\hline B2 & $\begin{array}{l}\text { Conhecimentos } \\
\text { de matemática, } \\
\text { contabilidade e } \\
\text { português. }\end{array}$ & Cursos, rotina. & $\begin{array}{l}\text { O volume de } \\
\text { trabalho }\end{array}$ & $\begin{array}{l}\text { Por meio da } \\
\text { organização. }\end{array}$ & $\begin{array}{l}\text { Passou a se } \\
\text { dedicar ao } \\
\text { trabalho com } \\
\text { mais atenção e } \\
\text { concentração. }\end{array}$ \\
\hline B3 & $\begin{array}{c}\text { Inovação, } \\
\text { agilidade, } \\
\text { paciência, saber } \\
\text { agir sob pressão. }\end{array}$ & $\begin{array}{l}\text { Experiências } \\
\text { de vida, } \\
\text { características } \\
\text { pessoais }\end{array}$ & $\begin{array}{l}\text { Férias do } \\
\text { colega de } \\
\text { Setor. }\end{array}$ & $\begin{array}{l}\text { Prestando } \\
\text { atenção aos } \\
\text { detalhes das } \\
\text { tarefas. }\end{array}$ & $\begin{array}{l}\text { Agilidade, } \\
\text { sagacidade, } \\
\text { domínio das } \\
\text { tarefas. }\end{array}$ \\
\hline B4 & $\begin{array}{l}\text { Legislação e } \\
\text { adoção de uma } \\
\text { postura atenta. }\end{array}$ & $\begin{array}{l}\text { Aprendeu com } \\
\text { os próprios } \\
\text { erros. }\end{array}$ & $\begin{array}{l}\text { Lidar com o } \\
\text { atendimento } \\
\text { ao público. }\end{array}$ & $\begin{array}{c}\text { Com a prática e } \\
\text { o tempo de } \\
\text { serviço. }\end{array}$ & $\begin{array}{l}\text { Ganhou } \\
\text { segurança, } \\
\text { domínio das } \\
\text { tarefas. }\end{array}$ \\
\hline B5 & $\begin{array}{l}\text { Legislação e } \\
\text { iniciativa. }\end{array}$ & $\begin{array}{l}\text { Estudando, } \\
\text { fazendo } \\
\text { estágios. }\end{array}$ & $\begin{array}{l}\text { Aprender a } \\
\text { legislação. } \\
\text { Não há } \\
\text { manuais. }\end{array}$ & $\begin{array}{l}\text { Correndo atrás, } \\
\text { buscando } \\
\text { informações e } \\
\text { com a vontade } \\
\text { de aprender. }\end{array}$ & $\begin{array}{l}\text { Mudança na } \\
\text { visão de } \\
\text { servidor } \\
\text { público, pró- } \\
\text { atividade. }\end{array}$ \\
\hline B6 & $\begin{array}{c}\text { Responsabilidade } \\
\text { e } \\
\text { comprometimento. }\end{array}$ & $\begin{array}{c}\text { Criação, } \\
\text { personalidade, } \\
\text { aprendeu com } \\
\text { a vida. }\end{array}$ & $\begin{array}{c}\text { Ter paciência } \\
\text { com o público } \\
\text { em geral e } \\
\text { com os } \\
\text { colegas. }\end{array}$ & $\begin{array}{l}\text { Por meio de } \\
\text { conversas com } \\
\text { colegas. }\end{array}$ & $\begin{array}{l}\text { Melhoria no } \\
\text { desempenho, } \\
\text { postura mais } \\
\text { tolerante. }\end{array}$ \\
\hline
\end{tabular}

Fonte: Elaborado pela autora.

Para esse grupo, o desenvolvimento dessas competências se deu por meio de cursos, de experiências anteriores em estágios e até mesmo estudando para concursos conforme explicitou o servidor B5 com a seguinte frase: "Muitas vezes, quando você está estudando para concurso você tem que estudar aquela legislação e não entende o porquê. Mas quando você chega aqui, na hora de botar a mão na massa, você vê que aquilo lá é muito importante."

Outro fator que merece destaque foi o ressaltado pelo servidor B4, que afirma que desenvolveu competências com os próprios erros, conforme depoimento a seguir: "No começo, eram erros bestas e que não deviam ter acontecido. Foi por 
falta de atenção e concentração. Passei a me concentrar mais no trabalho e tentar me desligar de tudo o que estava acontecendo."

Com relação aos principais desafios enfrentados por este grupo, chama a atenção o fato de que as opiniões divergiram bastante, porém, em dois casos específicos, percebe-se que a preocupação destes novos funcionários advém da insegurança causada pelo pouco tempo de serviço. Para o servidor B3, o maior problema enfrentado ocorreu quando o seu colega de setor entrou de férias. Este funcionário afirma o seguinte: "Eu tive que trabalhar sozinho aqui, por minha conta e risco, sem ter ajuda de ninguém. Além da pressão que vem de fora, foi algo que aconteceu que eu tive que fazer sozinho, me virar". Já para o servidor B4, que teve sua primeira experiência profissional como Assistente de Chancelaria, o maior receio era o trato com o público. Ela comentou que nos primeiros meses de serviço, ficava insegura só de receber uma ligação telefônica, pois não se sentia capaz de repassar informações para outras pessoas.

Os outros integrantes do Grupo B citaram outros fatores, como o entendimento da legislação e a adaptação ao serviço público. O servidor B1, membro mais velho do grupo, informa que teve diversas experiências profissionais, todas em empresas privadas. Este integrante afirma que "a máquina demora, é muita burocracia e muita papelada muitas vezes para uma coisa simples."

Para confrontar esses desafios, os indivíduos recorreram a estratégias que visavam, na maioria dos casos, um maior conhecimento das atividades desenvolvidas. O servidor B5, que teve problemas em aprender a legislação afirma que superou essa barreira "correndo atrás e tendo vontade de aprender e desempenhar um bom trabalho, mesmo não sendo muitas vezes reconhecido por essa responsabilidade toda".

Os servidores B2 e B3, que possuíam problemas principalmente com relação à insegurança, consideram que a prática diária os ensinou a desenvolver seu trabalho com maior rapidez e sagacidade. Para o servidor B1, que se sentia incomodado com a lentidão típica do serviço público, o meio encontrado foi a adaptação e o entendimento dos processos. O próprio servidor constata o seguinte: 
"tudo o que é baseado em lei tem sua demora, precisa da assinatura de um, da assinatura de outro, você começa a ter paciência e pensar: realmente, precisa disso, tem certas etapas que são necessárias, porque é o nome de muita gente que assina em jogo." (B1)

Dessa maneira, verifica-se o desenvolvimento de novas competências a partir do enfrentamento dessas dificuldades: concentração, capacidade de adaptação, flexibilidade. Porém o relato mais interessante partiu do servidor B5, que sugere que sua visão a respeito dos servidores público mudou e que o aprendizado é primordial para a execução do seu trabalho. Para exemplificar, ele coloca o seguinte:

\footnotetext{
"Antes eu não era servidor publico e hoje eu sou servidor publico. Eu sou. Eu tenho um amigo que fala assim: Você não está servidor público, você é servidor público. Justamente por isso que eu tenho essa vontade de querer aprender, de querer fazer um bom serviço, de querer resolver os problemas que devem ser resolvidos. A gente tem que correr atrás mesmo." (B5)
}

\subsubsection{Processos de aprendizagem}

No que diz respeito aos processos de aprendizagem, novamente a primeira opção para todos os integrantes deste grupo é recorrer aos colegas mais experientes. O servidor B1 explica: "meu método é o boca a boca. Saio gritando e perguntando: quem é que entende disso?". Em um segundo momento, os membros recorrem às leis, aos chefes e aos manuais que muitas vezes foram elaborados por eles próprios para facilitar o aprendizado, uma vez que todos são funcionários com pouco tempo de serviço.

Apesar disso, eles se consideram capazes de repassar seus conhecimentos para os outros e afirmam, inclusive, que costumam ser procurados para sanar dúvidas alheias, porém alguns sentem que ainda existem ressalvas, como informa o servidor B4: "me procuram de vez em quando, não sempre porque tem pouco tempo que eu entrei."

Quadro 6. Processos de aprendizagem, de acordo com respondentes do Grupo B

\section{\begin{tabular}{|l|l|l} 
Entrevistado & A quem recorre em caso de & E procurado em caso de dúvida?
\end{tabular}}



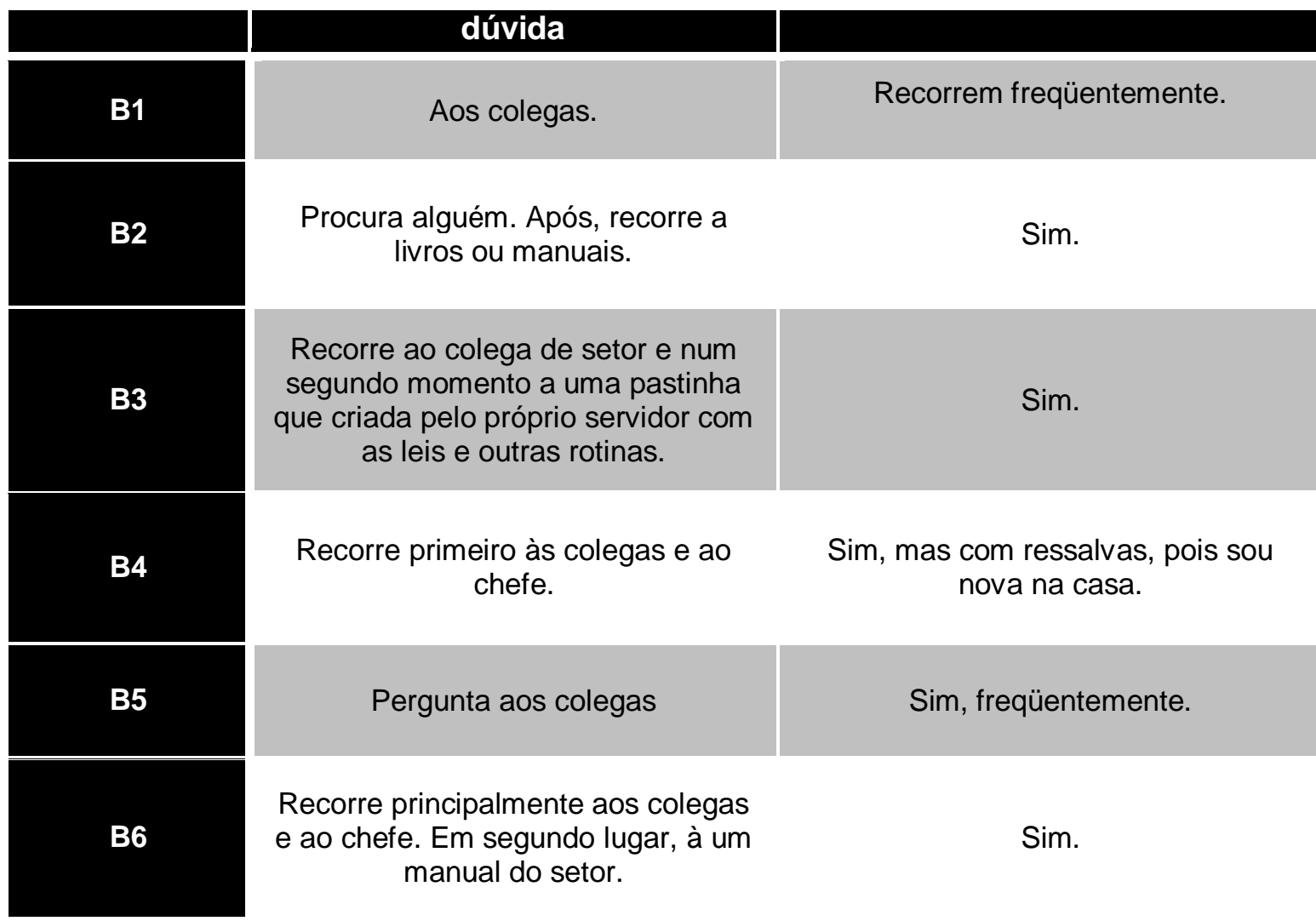

Procura alguém. Após, recorre a livros ou manuais.

Sim.

Recorre ao colega de setor e num segundo momento a uma pastinha que criada pelo próprio servidor com as leis e outras rotinas.

Sim.

Recorre primeiro às colegas e ao Sim, mas com ressalvas, pois sou chefe. nova na casa.

Pergunta aos colegas

Recorre principalmente aos colegas

e ao chefe. Em segundo lugar, à um manual do setor.
Sim.

Fonte: Elaborado pela autora.

\subsubsection{Redes sociais}

Quanto à maneira que os conhecimentos são repassados, os integrantes do Grupo B consideram que o principal é conversar, mostrando para o aprendiz como o trabalho deve ser feito, conforme disposto no Quadro 7.

Para exemplificar esta situação, o servidor B3, que está treinando um novo estagiário, explica: "vou mostrando primeiro como funciona e vamos colocando na prática aos poucos, pra ele ir pegando com calma e com o tempo ter mais segurança. Deixo o estagiário observando para pegar as peculiaridades dos processos". O servidor B4 também recebeu a incumbência de treinar um novo estagiário. Para ele, o processo de treinamento se deu da seguinte maneira: "em primeiro lugar eu dei para ele as leis, para ele ler e me perguntar caso tivesse alguma dúvida e as outras coisas eu mostrei, exemplifiquei e ele seguiu. Além disso, sempre que ele tem dúvidas, ele pergunta". 


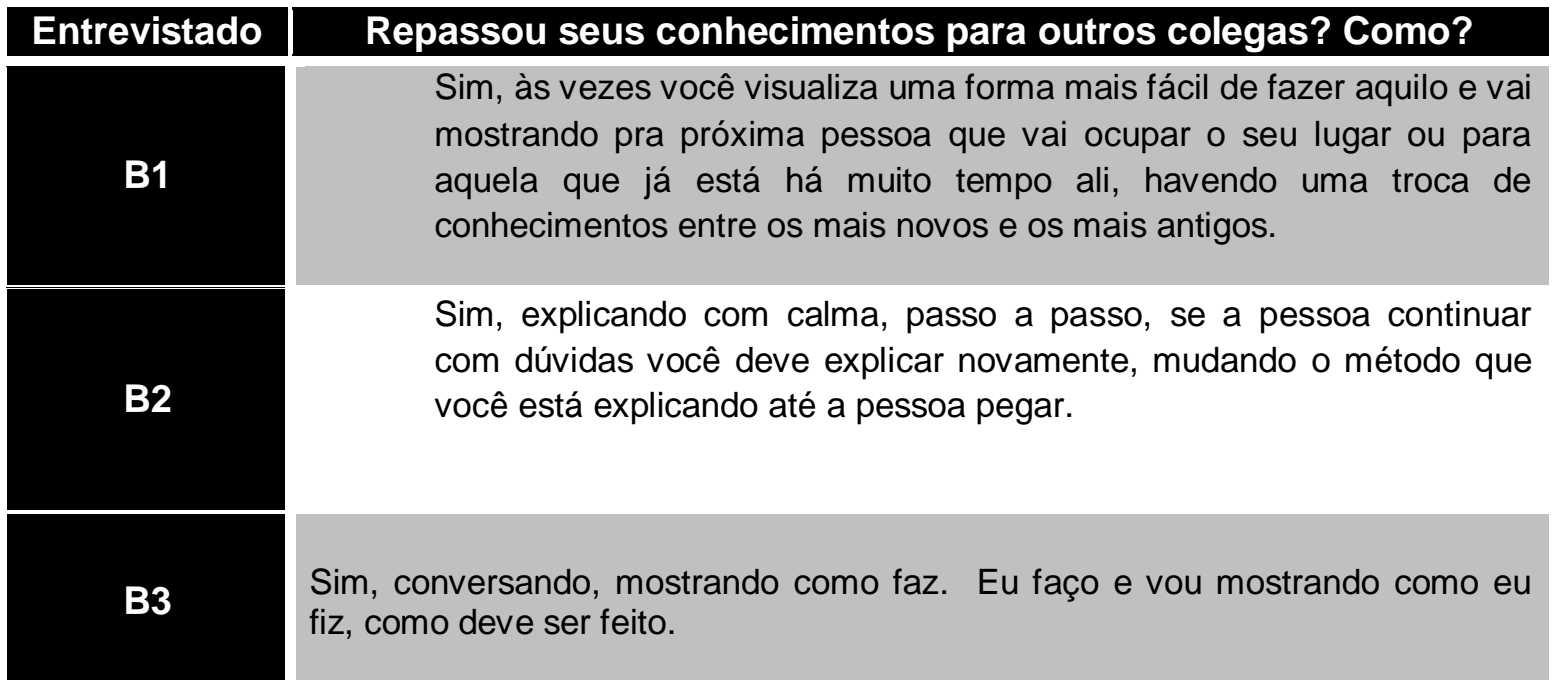

Sim. Em primeiro lugar eu dei para ele as leis, para ele ler e me perguntar caso tivesse alguma dúvida e as outras coisas eu mostrei, exemplifiquei e ele seguiu. Além disso, sempre que ele tem dúvidas, ele pergunta.

Sim, A partir de lições, ensinamentos, dicas, conversas, fazendo para a própria pessoa assistir e aprender. Como se fosse um aprendizado em sala de aula, entre professor e aluno ou entre dois amigos.

B5

B6

Sim, explicando, mostrando a legislação, com os cursos que eu fiz eu aprendi muita coisa nova que eu estou aplicando aqui e que eu preciso passar para os meus colegas também. E eles tão querendo aprender também. Fica mais fácil quando a pessoa tem um incentivo de querer aprender, te procura e você também quer ensinar. Isso é muito gratificante.

Fonte: Elaborado pela autora.

Outro depoimento que se sobressaiu foi o do servidor B6. Este funcionário foi designado pela chefia para realizar um curso externo. Ao retornar, ele deveria repassar o que aprendeu aos colegas de setor. Ele considera que essa experiência o trouxe benefícios como a confiança da equipe e a melhora da auto-estima, conforme explicou: "fica mais fácil quando a pessoa tem um incentivo de querer aprender, te procura e você também quer ensinar. Isso é muito gratificante".

Por fim, o servidor B1 enaltece a possibilidade da troca de conhecimentos, por meio do aprimoramento dos processos.

"Às vezes você visualiza uma forma mais fácil de fazer aquilo e vai mostrando pra próxima pessoa que vai ocupar o seu lugar ou para aquela que já está há muito tempo ali, havendo uma troca de conhecimentos entre os mais novos e os mais antigos". 
Nos relatos dos servidores B5 e B2, a principal forma de transferência de conhecimentos ocorre por meio do diálogo. É interessante perceber as similaridades entre a afirmação do servidor B5 e a afirmação do servidor A4. Para ambos, ensinar um colega remete às lições repassadas em uma sala de aula, por exemplo. O servidor B5 afirma que o aprendizado ocorre "a partir de lições, ensinamentos, dicas, conversas, fazendo para a própria pessoa assistir e aprender. Como se fosse um aprendizado em sala de aula, entre professor e aluno ou entre dois amigos."

\subsection{Análise comparativa entre os Grupos A e B}

Nesta etapa da pesquisa, propõe-se a comparação entre os resultados obtidos com os dois grupos, de modo a identificar possíveis diferenças com relação aos processos de aprendizagem.

Inicialmente, com base apenas na comparação entre os dados sóciodemográficos, verifica-se a diferença significativa entre as médias de idade existente entre os membros dos dois grupos. Para o Grupo A, a média é de 31 anos, enquanto que para o Grupo B, este valor é de 24 anos. Essa divergência influi claramente no teor das respostas dos participantes, principalmente percebida na questão que tratava dos principais desafios enfrentados durante a realização do trabalho.

\subsubsection{Desenvolvimento de competências}

No que diz respeito ao desenvolvimento de competências, os relatos obtidos pelos dois conjuntos de colaboradores demonstram que, analisando o que foi dito em consonância pelos dois grupos, as competências essenciais necessárias para o exercício do cargo de Assistente de Chancelaria são as seguintes: saber lidar com o público e com a pressão, bem como conhecimentos em legislação, informática e português.

Além dessas, diversas outras competências foram citadas exclusivamente pelo Grupo A, como por exemplo, a iniciativa, a fluência em línguas estrangeiras, a pró-atividade, a gestão de equipes e a cooperação. Pelos os membros do grupo $B$ 
foram citados ainda conhecimentos em matemática e contabilidade, paciência e responsabilidade. Essas divergências ocorreram principalmente por conta das diferenças das atividades desempenhadas pelos participantes, uma vez que os funcionários estão lotados em setores distintos. Ademais, os integrantes do Grupo A, por serem mais antigos na casa, desempenham papéis que possuem um escopo maior de atuação, desenvolvendo, assim, competências diferenciadas.

O desenvolvimento destas competências ocorreu de maneira similar pelos dois grupos. Foram citados como fatores determinantes para o desenvolvimento: as características pessoais, a criação recebida, outras experiências de trabalho, a realização de cursos, a prática, a observação e até mesmo estudos para a faculdade ou para concursos públicos.

Quanto aos principais desafios enfrentados, infere-se pelos relatos do grupo A, que a hierarquia existente no Ministério é um fator determinante na realização dos trabalhos. Os depoimentos expõem, na sua maioria, problemas relacionados à cultura organizacional. Já os integrantes do Grupo B citaram situações relacionadas sempre à realização das tarefas. Essa discrepância pode ser explicada pelo pouco tempo de casa que os servidores do Grupo B possuem, apenas oito meses. É possível que estes servidores não tenham absorvido ainda os valores da organização.

A partir do enfrentamento desses desafios, inquiriu-se aos servidores quais as novas competências que eles haviam adquirido. O servidor B1, o mais velho do grupo, que afirmou ter dificuldades em compreender a morosidade do serviço público. Para o restante dos servidores do Grupo B, as competências desenvolvidas por meio do enfrentamento dos desafios trouxeram benefícios sensibilizados principalmente no desempenho das atividades, tais como: domínio das tarefas, autoconfiança, segurança, pró-atividade e agilidade.

\subsubsection{Processos de aprendizagem}

Para os dois grupos de servidores entrevistados, a aprendizagem se dá, principalmente, por meio de processos informais. Conversas com colegas e chefes, reuniões, consultas a manuais e à legislação são os principais meios encontrados para sanar dúvidas. Este dado ratifica a idéia de que os processos de aprendizagem 
informal são primordiais para o desenvolvimento das competências necessárias para a atividade profissional desta classe de servidores.

É importante ressaltar que funcionários dos dois conjuntos analisados também citaram processos formais de aprendizagem, como, por exemplo, a participação em cursos para a aprendizagem de línguas.

As respostas dadas pelos dois grupos são bastante similares neste aspecto, sendo que todos afirmaram que, na ocorrência de dúvidas, procuram colegas em primeiro lugar. Exprimem, ainda, que também são procurados para a solução de questões relativas ao trabalho.

Com relação ao que foi discutido na revisão da literatura, verifica-se que as estratégias de aprendizagem citadas ratificam os principais conceitos identificados. Percebe-se a influência deliberada do Órgão ao patrocinar cursos e treinamentos para os funcionários, caracterizando assim processos de aprendizagem formal. Porém, o enfoque desta pesquisa visa identificar, especificamente, os processos naturais de aprendizagem. Este tipo de aprendizagem não pode ser determinado ou desenhado pela instituição.

\subsubsection{Redes sociais}

Com relação à importância das redes sociais para a transferência de informações e conhecimentos, verificou-se que os entrevistados de ambos os grupos consideram-se aptos a repassar o que sabem a outros funcionários, novamente utilizando processos informais. Para os dois conjuntos de servidores, a transferência de conhecimentos ocorre com base nas conversas, na observação, na leitura de textos e leis e até mesmo durante a prática das atividades, realizada com a assistência do colega que está ensinando.

Este é outro aspecto desta pesquisa em que houve semelhanças entre as repostas dadas pelos dois ramos examinados. 


\subsection{Discussão dos resultados}

Para McClelland e Dailey (1972, apud BORGES-ANDRADE; ABBAD; MOURÃO, 2006, p. 90), competências são, em síntese, "conjunto de características individuais observáveis, como conhecimentos, habilidades, objetivos e valores, capazes de predizer e/ou causar um desempenho efetivo ou superior no trabalho ou em outras situações da vida".

Algumas das características citadas pelos entrevistados como competências não se encaixam exatamente nos conceitos encontrados na literatura. É o caso do entrevistado B4, que afirmou ser necessária atenção para a realização de suas tarefas.

Com relação a outras competências citadas e passíveis de dúvida, como por exemplo, paciência, Borges-Andrade, Abbad e Mourão, (2006) consideram-na uma virtude essencial que facilita a integração em equipes interdisciplinares e heterogêneas. Para Bartlett e Gohshal (1987, apud BORGES-ANDRADE; ABBAD; MOURÃO, 2006, p. 92) as competências se classificam em três ramos:

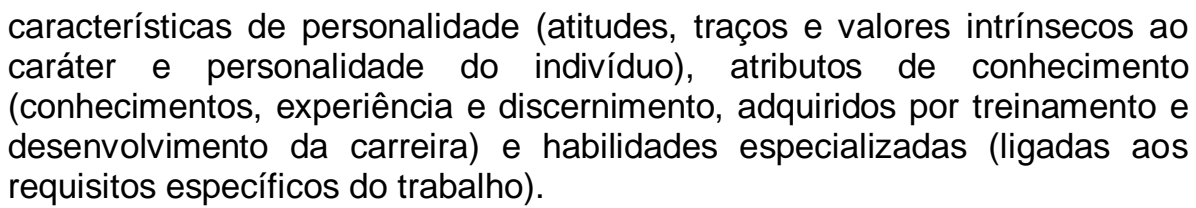

Com base nestes conceitos, podemos classificar as competências citadas pelos entrevistados de acordo com o Quadro 8.

Quadro 8. Competências citadas pelos entrevistados

\begin{tabular}{|c|c|c|c|}
\hline Grupo & Atitudes/traços & Conhecimentos & Habilidades \\
\hline A & $\begin{array}{l}\text { Iniciativa, cordialidade, pró- } \\
\text { atividade, cooperação, } \\
\text { tolerância. }\end{array}$ & $\begin{array}{l}\text { Informática, português, } \\
\text { legislação e língua } \\
\text { estrangeira. }\end{array}$ & $\begin{array}{l}\text { Saber lidar com o público, } \\
\text { flexibilidade, gestão de } \\
\text { equipes, visão holística dos } \\
\text { processos. }\end{array}$ \\
\hline B & $\begin{array}{c}\text { Disciplina, paciência, } \\
\text { agilidade, iniciativa, } \\
\text { comprometimento e } \\
\text { responsabilidade, } \\
\text { predisposição para } \\
\text { aprender. }\end{array}$ & $\begin{array}{l}\text { Informática, português, } \\
\text { legislação, matemática e } \\
\text { contabilidade. }\end{array}$ & $\begin{array}{l}\text { Saber agir sobre pressão, } \\
\text { atendimento ao público. }\end{array}$ \\
\hline \multicolumn{4}{|c|}{$\begin{array}{l}\text { Fonte: Adaptado de Barlett e Goshhal (1987 apud KILIMNIK; SANT'ANNA, 2006). } \\
\text { É importante frisar que as competências distribuídas no Quadro } 8 \text { não se }\end{array}$} \\
\hline
\end{tabular}


Por exemplo, saber lida com o público muitas vezes exige, ainda, conhecimentos e atitudes, e não apenas uma habilidade.

No que diz respeito aos processos de aprendizagem informal, percebemos que os resultados obtidos se assemelham com o de outras pesquisas realizadas com a mesma temática. Beviláqua-Chaves (2007), ao comparar estratégias de aprendizagem em um contexto de mudança, afirma que a "busca de ajuda interpessoal" foi identificada em sua pesquisa como a estratégia mais utilizada, corroborando os dados obtidos com este trabalho, uma vez que os Assistentes de Chancelaria entrevistados afirmaram recorrer inicialmente aos colegas em caso de dúvidas.

Os principais autores citados no referencial teórico consideram como estratégias de aprendizagem informal as conversas com colegas, as reuniões, 0 trato com os clientes, a observação e os esclarecimentos recebidos de supervisores. Estes foram exatamente os principais pontos levantados pelos entrevistados de ambos os grupos, demonstrando que, de fato, a aprendizagem informal se molda às necessidades do funcionário, pois está intimamente relacionada às necessidades específicas do trabalho. Isso ocorre porque, se durante a realização de uma tarefa, o servidor tiver alguma dúvida, recorrerá à aprendizagem informal. Dessa forma, o conhecimento adquirido servirá para um processo específico e será utilizado no mesmo momento, reforçando, assim, o conhecimento.

Ao analisar os resultados encontrados relacionados às redes sociais, verifica-se a confirmação dos conceitos explicitados na revisão da literatura. Percebe-se que há, no Ministério, a formação de grupos que compartilham objetivos e são movidos por relações de interesse. As redes são formadas, neste caso específico, principalmente por colegas de trabalho que estão lotados em um mesmo setor e que desenvolvem tarefas análogas.

Conforme proposto por Tomaél, Alcará e Di Chiara (2005), nessas situações, a rede age como um espaço de interação que possibilita a troca de informações e de conhecimentos, contribuindo para a dissolução de dúvidas e para a realização to trabalho. 


\section{CONSIDERAÇÕES FINAIS}

Para Abbad e Borges-Andrade (2004), competência pode ser compreendida como a capacidade que cada indivíduo possui de produzir resultados que visem ao alcance dos objetivos organizacionais. Neste contexto, Vasconcelos e Mascarenhas (2007) afirmam que o desenvolvimento de competências se trata de um processo histórico próprio de aprendizagem da organização, por meio do qual podem se consolidar comportamentos exclusivos daquele ambiente, de difícil reprodução. $O$ presente estudo buscou identificar essas competências, que permitem a descrição de comportamentos e atitudes únicas do grupo de estudo, no caso, ocupantes do cargo de Assistente de Chancelaria, carreira de nível médio do Serviço Exterior Brasileiro.

No que diz respeito ao alcance dos objetivos traçados por esta pesquisa, os relatos obtidos pelos dois conjuntos de colaboradores demonstra, que, de maneira geral, as competências necessárias identificadas para o exercício do cargo de Assistente de Chancelaria são as seguintes: disciplina, concentração, pró-atividade, cooperação, bom domínio do português, matemática, da legislação e de línguas estrangeiras, cordialidade, gestão de equipes, iniciativa, conhecimentos de matemática e de informática, saber lidar com o público, saber lidar com a pressão do trabalho, responsabilidade, comprometimento, tolerância, flexibilidade e capacidade de adaptação.

Com base no estudo realizado, conclui-se que os principais processos que propiciam a ocorrência da aprendizagem informal para os ocupantes do cargo de Assistente de Chancelaria são: conversas com colegas e chefes, reuniões, pesquisas em manuais e na legislação. Percebe-se, ainda, que não ocorrem distinções significativas quanto às estratégias de aprendizagem informal utilizadas pelos dois grupos de servidores.

Finalmente, com relação aos objetivos traçados, considera-se que foram atingidos e que os resultados encontrados podem contribuir na construção do conhecimento científico na área de aprendizagem no âmbito organizacional.

Cabe ressaltar que as perguntas adicionais, realizadas exclusivamente com Grupo A, merecem destaque por demonstrar que a possibilidade de trabalhar $\mathrm{e}$ morar fora do Brasil trouxe inúmeros benefícios aos servidores que tiveram essa 
oportunidade, bem como permitiram o desenvolvimento de outras competências, como a tolerância e a visão global dos processos realizados pelo Órgão.

Dessa maneira, propõe-se a realização de estudos que foquem principalmente em servidores que tiveram a possibilidade de trabalhar no exterior, uma vez que as dificuldades são maiores, inclusive com relação à comunicação, que normalmente é o primeiro fator utilizado em caso de dúvidas. Mesmo em curtos períodos de tempo, a aprendizagem foi, conforme identificado por meio das entrevistas, bastante enriquecedora.

Verifica-se, ainda, que, no que concerne às redes sociais, a pesquisa apresentou limitações. Apenas foi possível identificar que os servidores recorrem principalmente à colegas do mesmo setor e aos chefes, porém seria interessante traçar o contorno dessas redes.

Outro fator limitante deve-se ao fato de que os servidores entrevistados trabalhavam em departamentos e divisões diferentes, impossibilitando a visualização da rede. Para isso, sugerem-se pesquisas futuras, utilizando um escopo maior de entrevistados. Dessa forma, seria possível traçar as redes entre os diversos departamentos e o fluxo de informações.

Outra sugestão de estudo a ser realizado deve considerar a influência da hierarquia no clima organizacional, com uma análise dos valores e da cultura da organização. O ideal seria identificar se este fator pode atuar desmotivando os servidores, o que implicaria em desinteresse em aprender e em executar as tarefas com excelência.

Uma importante implicação prática deste estudo, para o dia a dia do Ministério das Relações Exteriores, está na descrição dos processos de aprendizagem informal utilizados para o desenvolvimento de competências.

Esses dados podem favorecer diagnósticos que fomentem políticas de gestão de pessoas cientificamente embasadas, especialmente no que concerne à transferência de conhecimento e à troca de informações, temáticas cada vez mais populares nos ambientes de trabalho atuais. 


\section{REFERÊNCIAS}

ABBAD, G. S.; BORGES-ANDRADE, J. E. Aprendizagem Humana em Organizações de Trabalho. In: ZANELLI, J. C.; BORGES-ANDRADE, J. E.; BASTOS, A. V. B. Psicologia, Organizações e Trabalho no Brasil. Porto Alegre: Artmed, 2004.

ANDRADE, M. M. Introdução à metodologia do trabalho científico. 7 ed. São Paulo: Atlas, 2005.

BABBIE, E. The practice of social research. 5.ed. Califórnia: Wadsworth, 1989. 501p.

BARReto, A. A. A condição da informação. São Paulo em Perspectiva, São Paulo, v. 16, n. 3, jul. 2002. Disponível em <http://www.scielo.br/scielo.php?script=sci.artte xt\&pid=S0102-88392002000300010\&lng=pt\&nrm=iso >. Acesso em: 20 abr. 2009.

BARROS, A. J. P.; LEHFELD, N. A. S. Fundamentos de metodologia: um guia para a iniciação científica. São Paulo: McGraw-Hill, 1986.

BASTOS, A. V. B.; GONDIM, S. M. G.; LOIOLA, E. Aprendizagem organizacional versus organizações que aprendem: características e desafios que cercam essas duas abordagens de pesquisa. RAUSP - Revista de Administração, v. 39, n. 3, jul./set, p. 220-230, 2004.

BAUMGARTEN, M.; TEIXEIRA, A. N.; LIMA, G. Sociedade e conhecimento: novas tecnologias e desafios para a produção de conhecimento nas ciências sociais. Sociedade e Estado, Brasília, v. 22, n. 2, ago. 2007. Disponível em <http://www.sci elo.br/scielo.php?script=sci_arttext\&pid=S0102-69922007000200007\&lng=pt\&nrm=is o>. Acesso em: 20 abr. 2009.

BEMFICA, J. C.; BORGES, M. E. N. Aprendizagem organizacional e informação. Ciência da Informação, Brasília, v. 28, n. 3, dez. 1999. Disponível em $<$ http://www.scielo.br/scielo. php?script=sci_arttext\&pid=S0100-19651999000300001 \&lng=pt\&nrm=iso>. Acesso em: 15 abr. 2009.

BEVILÁQUA-CHAVES, A. Estratégias de aprendizagem no Trabalho no Contexto de Mudança Organizacional. 2007. 104 f. Tese. (Mestrado em Psicologia Social, do Trabalho e das Organizações) - Instituto de Psicologia, Universidade de Brasília, Brasília.

BRASIL. Lei n. 8.829, de 22 de dezembro de 1993. Cria, no Serviço Exterior Brasileiro, as Carreiras de Oficial de Chancelaria e de Assistente de Chancelaria, e dá outras providências. Disponível em: http://www.planalto.gov.br/ccivil_03/LEIS/L88 29.htm. Acesso em: 17 abr. 2009

CARVALHO-SILVA, A. R. Clima Social da Organização, Motivação e Aprendizagem no Trabalho: 2008. 129 f. Tese (Mestrado em Psicologia Social, do Trabalho e das Organizações) - Instituto de Psicologia, Universidade de Brasília, Brasília. 
CERVO, A. L.; BERVIAN, P. A.; SILVA, R. Metodologia científica. 6. ed. São Paulo: Pearson Prentice Hall, 2007.

DRUCKER, P. F. Administrando para o futuro: os anos 90 e a virada do século. São Paulo: Pioneira, 1992.

DUARTE, R. Pesquisa qualitativa: reflexões sobre o trabalho de campo. Cadernos de Pesquisa, São Paulo, n. 115, Mar. 2002. Disponível em: http://www.scielo.br/sc ielo.php?script=sci_arttext\&pid=S0100-15742002000100005\&lng=en\&nrm=iso>. Acesso em: 10 jun. 2009.

FERREIRA, A. B. H. Novo dicionário Aurélio versão 5.0 edição revista e atualizada: Dicionário eletrônico. Curitiba: Positivo, 2006. 1 CD-ROM.

GIL, A. C. Como elaborar projetos de pesquisa. 3. ed.São Paulo: Atlas, 1991.

GIL, A. C. Métodos e Técnicas de Pesquisa Social. São Paulo; Ed. Atlas, 1999.

KILIMNIK, Z. M.; SANT'ANNA, A. S. Modernidade organizacional, política de gestão de pessoas e competências profissionais. In: BORGES-ANDRADE, J. E.; ABBAD, G. S.; MOURÃO, L. Treinamento, Desenvolvimento e Educação em Organizações de Trabalho: fundamentos para a gestão de pessoas. Porto Alegre: Artmed, 2006.

LEITE, J. B. D.; PORSSE, M. C. S. Competição baseada em competências e aprendizagem organizacional: em busca da vantagem competitiva. Revista de Administração Contemporânea, Curitiba, v. 7, n. spe, 2003. Disponível em $<$ http://www.scielo.br/scielo.php?script=sci_arttext\&pid=S1415-65552003000500007 \&lng=pt\&nrm=iso>. Acesso em: 28 abr. 2009.

LEORNARD, N.H. et al. The Impact of Group Cognitive Style on Strategic Decision Making and Organizational Direction. 1996. Disponível em: Http://www.cba.uri.edu/Scholl/Papers/Strategic-Groups.html. Acesso em: 20 abr. 2009.

LESCA, H.; ALMEIDA, F. C. Administração estratégica da informação. Revista de Administração, São Paulo, v. 29, n. 3, p. 66-75, jul./set. 1994. Disponível em <http://www.vsbrasil.com.br/artigo02.pdf>. Acesso em: 20 abr. 2009.

LOIOLA, E.; NÉRIS, J. S.; BASTOS, A. V. B. Aprendizagem em Organizações: mecanismos que articulam processo individuais e coletivos. In: BORGESANDRADE, J. E.; ABBAD, G. S.; MOURÃO, L. Treinamento, Desenvolvimento e Educação em Organizações de Trabalho: fundamentos para a gestão de pessoas. Porto Alegre: Artmed, 2006.

MACEDO, T. M. B. Redes informais nas organizações: a co-gestão do conhecimento. Ciência da Informação, Brasília, v. 28, n. 1, jan. 1999. Disponível em $<$ http://www.scielo.br/scielo.php?script=sci_arttext\&pid=S0100-19651999000100 014\&lng=pt\&nrm=iso $>$. Acesso em: 20 abr. 2009 
MARTELETO, R. M. Análise de redes sociais - aplicação nos estudos de transferência da informação. Ciência da Informação, Brasília, v. 30, n. 1, abr. 2001. Disponível em <http://www.scielo.br/scielo.php?script=sci_arttext\&pid=S0100-19652 001000100009\&lng=pt\&nrm=iso >. Acesso em: 20 abr. 2009.

MIGUEL, L. A. P.; TEIXEIRA, M. L. M. Valores organizacionais e criação do conhecimento organizacional inovador. Revista de Administração Contemporânea, Curitiba, v. 13, n. 1, Mar. 2009. Disponível em: http://www.scielo.br/scielo.php?script =sci_arttext\&pid=S1415-65552009000100004\&lng=en\&nrm=iso >. Acesso em: 14 abr. 2009.

MINISTÉRIO DAS RELAÇÕES EXTERIORES. Disponível em: www.mre.gov.br Acesso em: 12 abr. 2009.

MINISTÉRIO DAS RELAÇÕES EXTERIORES, Intranet. Disponível em: www.intratec.mre.gov.br. Acesso em: 12 abr. 2009.

NEVES, J. L.Pesquisa Qualitativa: características, usos e possibilidades. Caderno de Pesquisa em Administração, São Paulo (1), n. 3, 2ํ Sem. 1996, 103-113.

PARENTE, C. Conceitos de Mudança e Aprendizagem Organizacional: Contributos para a análise da produção de saberes. Sociologia. [online]. jan. 2006, no.50, p.89108. Disponível em: <http://www.scielo.oces.mctes.pt/scielo.php?script=lsci_arttext\& pid=S0873-65292006000100005\&Ing=pt\&nrm=iso>. Acesso em: 28 mar. 2009.

PERIN, M. G. et al. Processo de aprendizagem organizacional e desempenho empresarial: o caso da indústria eletroeletrônica no Brasil. RAE eletrônica, São Paulo, v. 5, n. 2, Dez. 2006. Disponível em: <http://www.scielo.br/scielo.php?script= sci_arttext\&pid=S1676-56482006000200005\&Ing=em\&nrm=iso >. Acesso em: 12 abr. 2009.

POZO, J. I. Aprendizes e Mestres: a nova cultura da aprendizagem. Porto Alegre: Artmed.

RICHARDSON, R. J. Pesquisa Social - Métodos e Técnicas. São Paulo; Ed. Atlas, 1999.

ROESCH, S. M. A. Projetos de estágio e de pesquisa em administração: Guia para estágios, trabalhos de conclusão, dissertações e estudos de caso. 3. ed. São Paulo: Atlas, 2007.

SILLAMI, N. Dicionário de Psicologia. Larousse/ Artmed. Porto Alegre: Artmed, 1998.

SOUZA, Y. S. Organizações de aprendizagem ou aprendizagem organizacional. RAE eletrônica, São Paulo, v. 3, n. 1, Jun. 2004. Disponível em: <http://www.scielo.b r/scielo.php?script=sci_arttext\&pid=S1676-56482004000100009\&lng=en\&nrm=iso >. Acesso em: 28 mar. 2009.

TAKAHASHI, A. R. W.; FISCHER, A. L. Aprendizagem organizacional e desenvolvimento de competências organizacionais: proposta metodológica para 
exploração conceitual empírica. Revista Economia \& Gestão da PUC Minas, Belo Horizonte, v. 8 n. 18, Set. 2008.

TOMAEL, M. I.; ALCARA, A. R.; DI CHIARA, I. G. Das redes sociais à inovação. Ciência da Informação, Brasília, v. 34, n. 2, Ago. 2005. Disponível em: <http://www. scielo.br/scielo.php?script=sci_arttext\&PID=S0100-19652005000200010\&lng=em\&nr $\mathrm{m}=$ iso $>$. Acesso em: 31 mar. 2009.

VASCONCELOS, I. F. G.; MASCARENHAS, A. O. Organizações em Aprendizagem. São Paulo: Thomson/pioneira. 2007.

YIN, R. K. Estudo de Caso: Planejamento e Métodos. Tradução Daniel Grassi. 3 ed. Porto Alegre: Bookman, 2005. 


\section{APÊNDICES}

\section{Apêndice A: Roteiro de Entrevista}

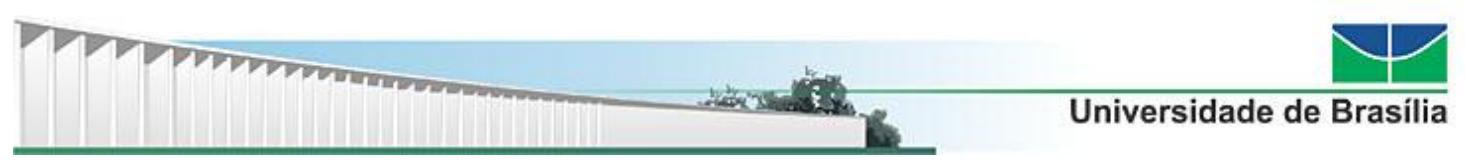

Faculdade de Economia, Administração, Contabilidade e Ciência da Informação e Documentação - FACE

Departamento de Administração - ADM

\section{Roteiro de Entrevista}

Esta pesquisa, desenvolvida para elaboração de monografia de conclusão do curso de Administração da UnB, por Aline de Aguiar Belsito dos Santos, visa identificar e descrever como ocorre a aprendizagem informal de competências necessárias à atuação profissional no exercício do cargo de Assistente de Chancelaria.

Os dados coletados terão finalidade acadêmica e serão tratados de modo que se mantenha o anonimato de pessoas. Ou seja, seu nome não será mencionado nos relatórios e documentos gerados a partir da pesquisa

Não existem respostas certas ou erradas. O que importa é a percepção de cada entrevistado a respeito do que será perguntado.

Considerando a facilidade para recuperação das informações solicitamos sua permissão para gravar a entrevista. Isso facilitará sobremaneira a entrevista e o aproveitamento das informações dadas por você.

Neste estudo consideramos competência como o "conjunto de conhecimentos, habilidades e atitudes que um indivíduo mobiliza para alcançar um determinado propósito no trabalho" (ABBAD; BORGES-ANDRADE, 2004, p. 240) e que o desenvolvimento de competências ocorrem, principalmente, por meio de processos de aprendizagem. Entendemos ainda que nem todas as situações que geram aprendizagem são decorrentes de ações formais de treinamento, desenvolvimento e educação. $O$ aprendizado também pode ocorrer por meio de 
mecanismos informais, tais como: conversas, reuniões, leitura de manuais, tentativa e erro.

\section{Desenvolvimento de Competências}

1.1 Quais competências são importantes para a realização do seu trabalho?

1.2 De que forma você desenvolveu as competências necessárias para a realização do seu trabalho?

1.3 Quais foram os principais desafios e/ou problemas que você enfrentou na realização de seu trabalho, até o momento?

1.4 Como você conseguiu superar esses desafios e/ou resolver esses problemas?

1.5 Que competências você acredita ter desenvolvido a partir do enfrentamento desses desafios/problemas?

\section{Processos de Aprendizagem}

2.1 Em caso de dúvida a quem ou a o que você costuma recorrer?

2.2 Seus colegas recorrem à você em caso de dúvidas?

\section{Redes sociais}

3.1 Você acredita que conseguiu repassar seus conhecimentos para outros colegas? Quais (indicar o nome)? De que maneira?

\section{Perguntas adicionais, exclusivas para o grupo de 2005}

4.1 Você teve a oportunidade de morar ou trabalhar no exterior em decorrência de sua atuação profissional?

4.2 Quais foram os principais desafios e/ou problemas que você enfrentou na realização de seu trabalho, no exercício de seu trabalho no exterior?

4.3 Como você conseguiu superar esses desafios e/ou resolver esses problemas?

4.4 O que você acha que aprendeu com essa experiência que trouxe benefícios para o seu desempenho profissional?

\section{Dados Sócio-demográficos e funcionais}

Sexo: M ( ) F( )

Idade:

Estado Civil:
Escolaridade:

Lotação:

Tempo de serviço no Ministério: 


\section{ANEXOS}

\section{Anexo A: Organograma do Itamaraty}

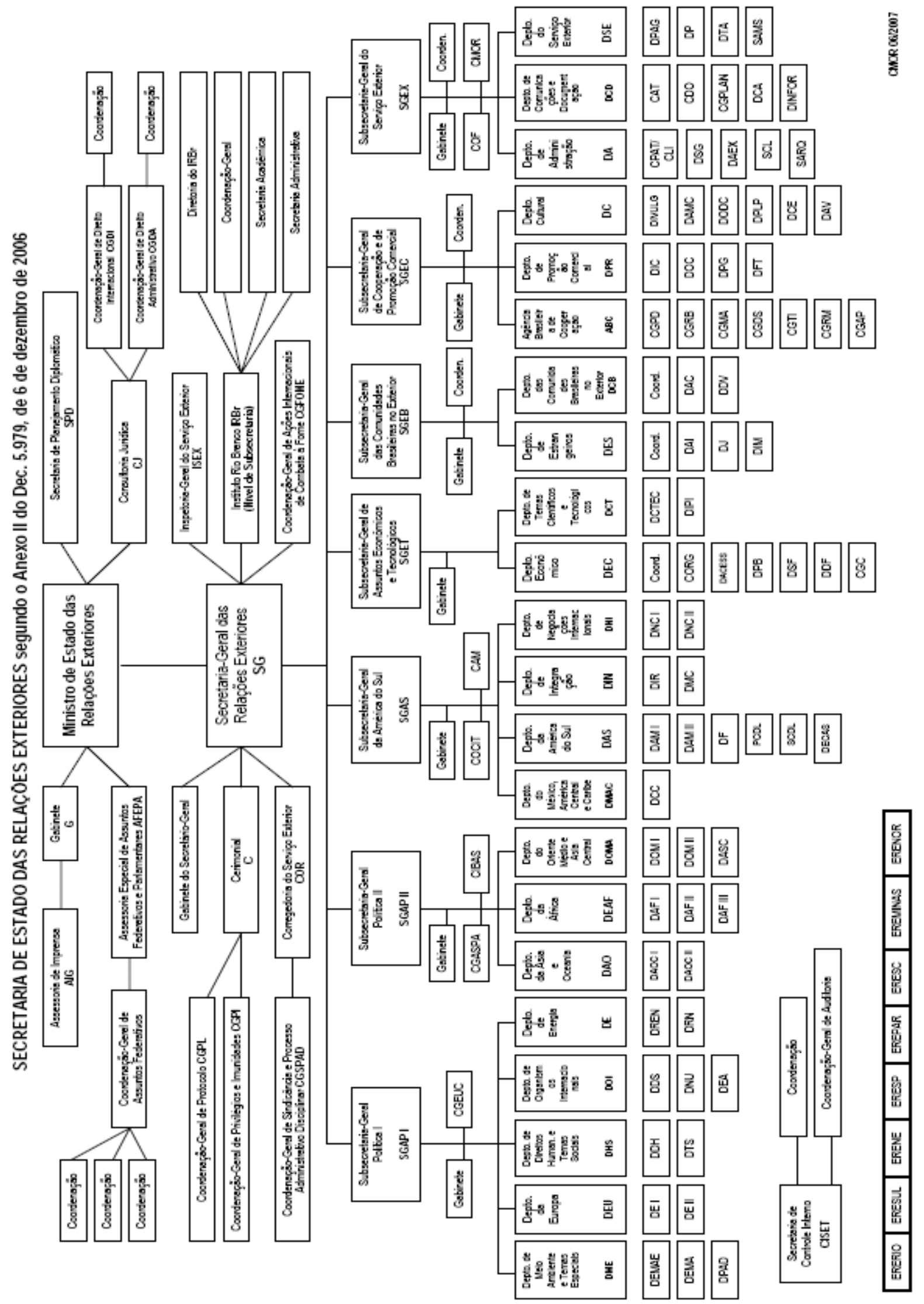

